archives-ouvertes

\title{
Relativisation in Wobzi Khroskyabs and the integration of genitivisation
}

\author{
Lai Yunfan
}

\section{To cite this version:}

Lai Yunfan. Relativisation in Wobzi Khroskyabs and the integration of genitivisation. Linguistics of the Tibeto-Burman Area, Dept. of Linguistics, University of California, In press. < halshs-01907013>

\section{HAL Id: halshs-01907013 https://halshs.archives-ouvertes.fr/halshs-01907013}

Submitted on 28 Oct 2018

HAL is a multi-disciplinary open access archive for the deposit and dissemination of scientific research documents, whether they are published or not. The documents may come from teaching and research institutions in France or abroad, or from public or private research centers.
L'archive ouverte pluridisciplinaire HAL, est destinée au dépôt et à la diffusion de documents scientifiques de niveau recherche, publiés ou non, émanant des établissements d'enseignement et de recherche français ou étrangers, des laboratoires publics ou privés. 


\title{
Relativisation in Wobzi Khroskyabs and the integration of genitivisation
}

\author{
Lai Yunfan \\ Max Planck Institute for the Science of Human History
}

\begin{abstract}
This paper focuses on the morphosyntax as well as the semantics of relativisation in Wobzi Khroskyabs, a Rgyalrongic language spoken in Sichuan, China. Different strategies of relativisation are presented, especially the nominalisation strategy. Wobzi Khroskyabs exhibits an innovative relativisation strategy with the genitive marker $=j i$, which is rarely found in other Rgyalrongic languages. Several hypotheses are put forward to account for the evolutionary pathway from genitivisation to relativisation, showing that genitive $=j i$ probably followed an ergative pattern to enter the relativisation of core arguments.
\end{abstract}

Keywords: Relativisation; genitive; complementation; Khroskyabs; Wobzi; TibetoBurman; Trans-Himalayan languages; Sino-Tibetan; Morphosyntax; grammaticalisation

\section{Background information}

Khroskyabs is one of the Rgyalrongic languages ${ }^{1}$ in the Trans-Himalayan (or Sino-Tibetan, see Owen-Smith and Hill 2014: 4) family, spoken in Rngaba Prefecture, Western Sichuan. With around 10,000 native speakers (Huang 2007), this language is surrounded by SouthWestern Mandarin Chinese, which is overwhelmingly dominant, and Amdo Tibetan, a highly prestigious language used for religious purposes. Therefore, even though Khroskyabs is fairly well preserved and transmitted to the younger generation, it is still under the threat of extinction.

Previous accounts on Khroskyabs mainly focus on morphology, such as Lai (2015) on its argument indexation, and Lai (2016) on its causativisation. However, a study on sentential constructions of this language is yet to see the light of day. This article is therefore dedicated to relative constructions of Wobzi, a Khroskyabs dialect spoken in the hamlet of sâgu (娃姑), Érè county (俄热乡).

\footnotetext{
${ }^{1}$ Rgyalrongic languages include Rgyalrong languages (Situ, Japhug, Zbu and Tshobdun), Khroskyabs and Horpa-Stau.
} 
In Section 2, I present fundamental typological features of Khroskyabs that are related to relativisation. Then in Section 3, an overview of relativisation in Wobzi is presented, focusing on the strategies, the places where the head noun can appear, and argument indexation within relative clauses. Section 4 deals with the most common way of relativisation in Wobzi Khroskyabs, the nominalised relative clauses. In Section 5, an interim summary is provided, before an account on correlative constructions in Section 6 . Section 7 and Section 8 focus on a particular type of relative construction, marked with the genitive enclitic $=j i$. I will first present its distribution, illustrated with examples, and then propose hypotheses on the way that the genitive marker manages to become a relative marker in Wobzi Khroskyabs.

\section{Typological features}

In this section, I will present essential typological features of Wobzi Khroskyabs. The noun (Section 2.1) and the verb (Section 2.2) are the two fundamental word classes in Wobzi Khroskyabs, it is therefore important to know how they function in order to understand the behaviours of relative constructions. The structure of the noun phrase (Section 2.1.1) helps the reader to understand the relation between the head noun and the relative clause, and argument flagging (Section 2.1.2) identifies syntactic roles of arguments. Argument indexation (Section 2.2.1) is one of the most important features of the Wobzi verb that affects fundamentally the meaning of the construction in question. TAM categories (Section 2.2.2), especially modality, as I will analyse further below, are related to the P-relativisation in Wobzi Khroskyabs. Nominalisation, the main strategy of relativisation in this language which will be used through our paper, is presented in Section 2.3 .

\subsection{The noun phrase}

\subsubsection{Noun phrase structure}

The basic noun structure in Wobzi Khroskyabs is illustrated in Table 1:

Table 1: Wobzi noun phrase structure

\begin{tabular}{c|c|c|c|c|c|c|c|c|c}
\hline-3 & -2 & -1 & 0 & 1 & 2 & 3 & 4 & 5 & 6 \\
\hline GEN & DEM & NOM & Head Noun & ADJ & NUM + (CL) & DEF & NUMBER & CASE & TOP \\
\hline
\end{tabular}

GEN: noun phrase marked with genitive DEM: demonstrative NOM: nominal modifier(s) ADJ: adjectival modifier(s)
$\mathrm{NUM}+(\mathrm{CL}):$ numeral + (classifier) NUMBER: grammatical number, dual or plural CASE: case marker TOP: topic marker

The examples in (1) illustrate elaborate noun phrases in bold. The example (1a) shows 
a noun phrase in which the head noun, $\chi p æ t^{h} \hat{v} \eta$ 'sword', is preceded by a demonstrative marker, $c \hat{\partial}$, and followed by the definite marker $=t \partial$, the instrumental $=\gamma \partial$ and a topic marker $=r$. In (1b), the head noun is preceded by a relative clause, presented between brackets, and followed by the definite $=t o$ and the dative $=k^{h} e$. The example (1c) shows a noun phrase marked by the genitive $=j i$ before the head noun and the example (1d) an adjectival modifier right after the head noun.

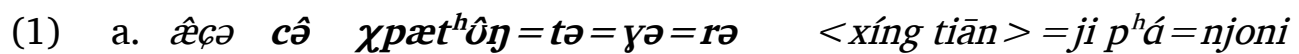
CONJ DEM sword $=\mathrm{DEF}=\mathrm{INSTR}=\mathrm{TOP}$ Xíngtiān $=\mathrm{GEN}$ mountain $=$ like bû̀ $=$ tə $\quad n-u-r c^{h} \grave{\partial}=s i$ head $=$ DEF PST-INV-split ${ }_{2}=$ IFR Then this sword broke Xíngtiān's mountain-like head open.

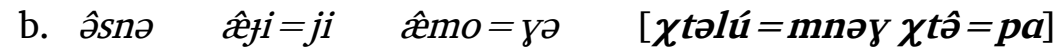

one.day $3 \mathrm{PL}=\mathrm{GEN}$ mother $=$ ERG hat $=$ red $\quad$ wear $_{1}=$ NMLZ:A

məlé $=$ tə $=k^{h} e .$.

girl $=\mathrm{DEF}=\mathrm{DAT}$

One day, the mother said to the girl wearing a red hat...

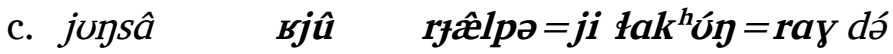
additionally bamboo king $=$ GEN temple $=$ one $_{\text {exist }}$ Additionally, there is the Bamboo King's temple.

d. jêeji jáy sô-qha snâ $n$-u-səsá=si $3 \mathrm{SG}=$ GEN hand SUPERL-big suddenly PST-INV-wipe ${ }_{2}=$ IFR He wiped his huge hands.

\subsubsection{Argument flagging}

The ergative alignment in Wobzi Khroskyabs is not canonical. The $\mathrm{S}$ and the $\mathrm{P}$ are always unmarked. The ergative marker $=\gamma \partial$ only appears on the A in inverse and $3 \leftrightarrow 3$ scenarios (see Section 2.2.1). Therefore, the scenarios $1 \rightarrow 2,1 \rightarrow 3$ and $2 \rightarrow 3$ prohibit ergative marking, despite the transitive construction.

(2) a. $\eta \hat{o}(*=y \partial)$ nû $v d e ́-n$

$1 \mathrm{SG}(*=\mathrm{ERG}) 2 \mathrm{SG} \mathrm{see} 2-2$

I saw you.

b. $n \hat{u}=y \partial \quad \eta \hat{o} \quad u-v d-a ́ \eta$

$2 S G=E R G$ 1SG INV-see 2 -1SG

You saw me.

Wobzi Khroskyabs presents a genitive-allative $=j i$ with examples illustrated in (3).

(3) a. Genitive

tsacî $=j i \quad k a p \hat{o}$

Bkrashis $=$ GEN book

Bkrashis' book 
b. Allative

$$
\begin{aligned}
& \eta \hat{x}=j i \quad \text { rnamá } \quad p^{h} \partial ́ l=p a \quad k \partial-v æ ́-n=n i \\
& \text { 1SG=ALL face.cream offer } 1=\text { NMLZ:P IMP-bring }_{3}-2=\mathrm{IMP} \\
& \text { Bring me a face cream as a gift! }
\end{aligned}
$$

Other markers include dative-ablative $=k^{h} e$, comitative $=s c e$, instrumental $=\gamma \partial$ (shared by the ergative), and various locative markers, $=t^{h} a$ (on the surface), $=g \partial$ (inside), =vi (under), etc.

\subsection{The verb}

\subsubsection{Argument indexation}

Transitive and intransitive verbs are morphologically distinct in Wobzi Khroskyabs, as shown in Table 2 and 3.

Intransitive verbs index invariably the $\mathrm{S}$. First person distinguishes the singular from the plural, with the suffixes $-\eta j$ and $-j$; second person is not differentiated in number, with

\begin{tabular}{|c|c|c|}
\hline & Suffixes & Pronouns \\
\hline $1 \mathrm{sg}$ & $\Sigma-\eta$ & $\eta \hat{O}$ \\
\hline $1 \mathrm{du}$ & $\sum-j$ & ngône \\
\hline $1 \mathrm{pl}$ & $\Sigma-j$ & gәرһfर, $\eta g \hat{\imath}$ \\
\hline $2 s g$ & $\sum-n$ & $n \hat{u}$ \\
\hline $2 \mathrm{du}$ & $\sum-n$ & nêne \\
\hline $2 \mathrm{pl}$ & $\sum-n$ & nênłi \\
\hline $3 s g$ & $\Sigma$ & ætô \\
\hline 3du & $\Sigma$ & ætône \\
\hline $3 p l$ & $\Sigma$ & ætôłi \\
\hline
\end{tabular}
the suffix $-n$; third person is unmarked.

Table 2: Intransitive paradigme in Wobzi Khroskyabs

In transitive constructions, the verb can index two arguments, the A and the P. Wobzi Khroskyabs exhibits a hierarchical alignment (Silverstein 1976), with first person ranking the highest, third person the lowest, and second person in between in the empathy hierarchy (DeLancey 1981), see (4).

(4) Empathy hierarchy in Wobzi Khroskyabs First person $>$ Second person $>$ Third person

When a first or second person is involved, the suffix of the transitive verb indexes the $\mathrm{P}$. When a third person is the $\mathrm{P}$, it is the A which is indexed by the suffix. In inverse scenarios, that is, $2 \rightarrow 1,3 \rightarrow 2$ and $3 \rightarrow 1$, an additional prefix, the inverse marker $u$-, must 
occur on the verb. In scenarios between two third persons, the inverse prefix occurs only when an orientational prefix ${ }^{2}$ is present.

Table 3: Transitive paradigme in Wobzi Khroskyabs

$\begin{array}{llllll} & 1 \mathrm{sg} & 1 \mathrm{pl} & 2 & 3 \\ & 1 \mathrm{sg} & & & \sum-n & \sum-\eta \\ 1 \mathrm{pl} & & & \sum-n & \sum-j \\ 2 & u-\sum-\eta & u-\sum-j & & \sum-n \\ 3 & u-\sum-\eta & u-\sum-j & u-\sum-n & (u)-\Sigma\end{array}$

Two ditransitive constructions are attested, indirective and secundative, following the terms by Malchukov et al. (2010). In an indirective construction, the $\mathrm{T}$ (theme, the direct object in ditransitive constructions) is indexed by argument indexation as the $P(T=P)$, while in a secundative construction, it is the $R$ that is indexed as the $P(R=P)$.

(5) a. Indirective: $k^{h} \hat{a}$ 'to give'

$n \hat{u}=$ yə $\quad \eta \hat{a}=k^{h} e \quad k a p \hat{~ r a ̂ y ~ n \partial-k^{h} a ́-n}$

$2 \mathrm{SG}=\mathrm{ERG} 1 \mathrm{SG}=\mathrm{DAT}$ book one PST-give ${ }_{2}-2$

You gave me a book.

b. Secundative: Idzê 'to teach'

$n \hat{u}=$ yə $\quad \eta \hat{a}=k^{h} e \quad$ bódzədə n-u-ldz-án

2SG $=$ ERG 1SG $=$ DAT Tibetan PST-INV-teach 2 -1SG

You taught me Tibetan.

\subsubsection{Stem alternation and TAM Categories}

Dynamic verbs in Wobzi distinguishes two tenses, non-past and past, while stative verbs distinguishes further past imperfective and perfective within the past tense.

A verb in Wobzi can present up to three stems, although most verbs have only two, and only a handful do not exhibit stem alternation. Stem 1 is the default stem, used for the non-past; Stem 2 is used in past and perfective situations and Stem 3 in irrealis situations. Four major stem alternation strategies are attested, tone alternation, rime alternation, aspiration alternation and suppletion, summarised in Table 4.

\footnotetext{
${ }^{2}$ Wobzi Khroskyabs, as well as the other Rgyalrongic languages, presents a series of orientational prefixes indicating the direction of the action denoted by the verb: $\mathfrak{x}$ - 'upwards', næx- 'downwards', $k \partial$ - 'upstream', nə'downstream', læ- 'towards the left bank', və- 'towards the right bank', rə- 'unknown direction'. Orientational prefixes are also used as TAME markers for most of the verbs.
} 
Table 4: Wobzi Stem Alternation

\begin{tabular}{|c|c|c|c|}
\hline Stem 1 & Stem 2 & Stem 3 & Gloss \\
\hline$n t s^{h} \hat{\partial}$ & $\mathrm{N} / \mathrm{A}$ & $\mathrm{N} / \mathrm{A}$ & to think \\
\hline$s r \hat{1}$ & srí (tone) & N/A & to look \\
\hline$r t s^{h} \not ́ x$ & rtshîn (rime) & $\mathrm{N} / \mathrm{A}$ & to try, to challenge \\
\hline tô & $t^{h} O ́$ (aspiration) & N/A & to arrive \\
\hline$v \hat{\partial}$ & $6 \hat{\partial}$ (suppletion) & cǽ (rime) & to go \\
\hline
\end{tabular}

Alternated stems alone are usually not sufficient to form inflected verbs expressing different TAM categories. Past and perfective forms, for example, usually take an orientational prefix, which is mostly lexically determined. As in the examples in (6), næ'downwards' is lexically assigned to the verb vî 'to do' in the past tense in (6a), and no'downstream' to the stative verb $m p^{h}$ jær r 'to be beautiful' as a perfective marker.

(6) a. ætâ=joni skavlê næ-v-án zdár $\mathrm{DEM}=$ like drudgery PST- $\mathrm{do}_{2}-1 \mathrm{SG}$ have.experience I did such a drudgery.

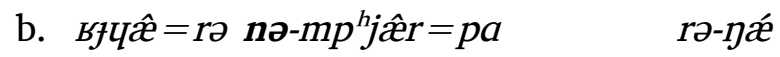
fox $=$ TOP PFV-be.beautiful ${ }_{2}=$ NMLZ NPST-be $_{1}$ The fox has become beautiful.

\subsubsection{Finiteness}

Unlike Rgyalrong languages, in which finiteness plays an important role in relativisation (Jacques 2016b, Sun 2006), finiteness is not essential to Khroskyabs relativisation. As Lai (2017) states, the only recognisable non-finite form in Wobzi Khroskyabs is the infinitive, which can be identified under certain conditions. The most common way to identify an infinitive is through a Stem 1 transitive verb without person indices, meanwhile free from inverse marking on the orientational prefix, see Example (7):

(7) $t^{h} æ \eta \hat{\partial} m=s k a \quad s m \hat{x ̂ n} \quad \boldsymbol{k} \boldsymbol{\partial}-\boldsymbol{v} \hat{\mathbf{i}}=p a \quad$ mí be.ill ${ }_{1}=$ NMLZ:time medicine INF-do $_{1}=$ NMLZ:A not.exist $_{1}$ When ill, there is no one to take care of them.

If a transitive verb is finite and has an orientational prefix, but lacks a person suffix, it must be conjugated in third person, which requires an obligatory inverse prefix, otherwise, the verb is non-finite. For instance, Example (8) is also grammatical with the same meaning compared to Example (7), with the only difference being that the verb form $k$-u-vî (NPST-INV-do ${ }_{1}$ ) is finite, with the inverse marker present.

(8) $t^{h} æ \eta \hat{m} m=s k a \quad$ smæ̂n $\quad \boldsymbol{k}$-ul-vî $=p a \quad$ mí be.ill ${ }_{1}=$ NMLZ:time medicine NPST-INV-do ${ }_{1}=$ NMLZ:A not.exist ${ }_{1}$ When ill, there is no one to take care of them. 


\subsection{Nominalisation}

Nominalisation in Wobzi can be achieved by various means: zero derivation, tone alternation, prefixation and encliticisation.

In zero derivation, the derived nominal stays formally unchanged compared to the base verb:

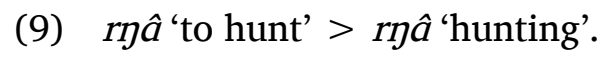

This strategy usually derives action nouns from corresponding verbs.

Some high-falling toned verbs derive corresponding nominals through shifting the tone into a high one, and the reverse tone alternation is not attested:
a. $d z \hat{1}$ 'to eat' $>d z i$ 'food'
b. $t^{\text {h }} \hat{e}$ 'to drink' $>t^{\text {he }}$ 'food, drink'
c. $f s \hat{\jmath}$ 'to sharpen' $>$ fsá 'iron forging'.

Prefixation is rare but not unattested, see for instance Example (11).

$$
s-p^{h} \text { ว́m 'lid' < phám 'to cover'. }
$$

The prefix $s$ - is unproductive and is cognate to an oblique nominaliser from a SinoTibetan perspective: $s \gamma$-in Rgyalrong (Japhug): $s \gamma$-cuu (NMLZ:O-open) 'key (instrument for opening)' (Jacques 2008: 46); $s$ - in Tibetan: 적' sbud 'bellows' from ఇהु' 'bud 'to blow'; "s-in Old Chinese, 朔 "s-prak 'first day of month (when the moon changes from waning to waxing)' from 屰 "prak 'to go against'3.

The most common way is through nominalising enclitics (hereafter nominalisers) of different semantic functions, applied to verb forms to derive corresponding nominal forms.

Table 5: Nominalising enclitics

\begin{tabular}{l|l}
\hline Enclitic & Gloss \\
\hline \hline$=p a,=\eta k^{h} \partial /=m k^{h} \partial$ & P/T (realis), S/A \\
\hline$=s p i$ & P/T (irrealis) \\
\hline$=s k a,=l v \eta k^{h} a$ & Time \\
\hline$=r i /=r e$ & Oblique (place, instrument, R) \\
\hline
\end{tabular}

The nominalisers listed above can be used for both lexical and clausal nominalisations. The difference between lexical and clausal nominalisation is discussed in Shibatani (2009: 191-194), Givón (1990: 498-501) and Genetti et al. (2008: 98-99). Lexical nominalisation in Wobzi is characterised by a formally unconjugated Stem 1 verb, with potential semantic idiosyncrasy. $p^{h} a-d_{z} \hat{e}-r i$ (mountain-hold ${ }_{1}$-NMLZ:instrument), literally meaning the instrument to own the mountain, is now used to translate the Chinese term

\footnotetext{
${ }^{3}$ I follow Baxter and Sagart (2014)'s reconstruction for Old Chinese.
} 
镇山之宝 zhèn shān zhì băo, referring to the most important treasure in the mountain. Clausal nominalisation does not identify the entity or event denoted by the clause itself, lacking specification (Shibatani 2009: 192). Clausal nominalisation plays an important role in complex sentential constructions, including the relatives, to be discussed in this paper.

\section{Overview of Wobzi Relativisation}

\subsection{Which arguments to relativise}

Keenan and Comrie (1977: 66) put forward the NOUN PHRASE ACCESSIBILITY HIERARCHY based on some 50 typologically distinct languages around the world, predicting the degrees of accessibility of different arguments to relativisation. Example (12) shows the ranking of the arguments, from the most accessible to the least.

(12) Accessibility Hierarchy SUBJECT $>$ DIRECT OBJECT $>$ INDIRECT OBJECT $>$ OBLIQUE $>$ GENITIVE $>$ OBJECT OF COMPARISON

As far as what Keenan and Comrie (1977) call the primary relativising strategy is concerned, the accessibility of a lower-ranking type of arguments implies that any higherranking type is accessible to relativisation as well. For instance, if a language can relativise the object of comparison, ranking as the least accessible, it must be able to relativise all the other types in the Hierarchy.

The most common strategy in Wobzi, gapping through nominalisation (see Section 3.2), does not contradict the Accessibility Hierarchy: except the object of comparison, all the other types of arguments in the Hierarchy are accessible to relativisation, including the $S$ of intransitive constructions and the $\mathrm{A}$ in transitive/ditransitive ones, the $\mathrm{P}$ in transitive constructions and the $\mathrm{T}$ in ditransitive constructions, oblique arguments such as the place and instrument adjuncts as well as time adjuncts. We will also see in this paper that not all strategies observed in the language follow entirely the Hierarchy, for instance, the one with the genitive $=j i$.

\subsection{Relativising strategies}

Of the four relativising strategies observed in Comrie and Kuteva (2005) ${ }^{4}$, three are attested in Wobzi Khroskyabs, that is, non-reduction, pronoun retention and gapping, summarised in Table 6.

\footnotetext{
${ }^{4}$ Relative pronoun, non-reduction, pronoun retention and gapping.
} 
Table 6: Relativising strategies

\begin{tabular}{lc}
\hline Strategy & Existence in Wobzi \\
\hline Relative pronoun & $\boldsymbol{x}$ \\
Non-reduction & $\checkmark$ \\
Pronoun retention & $\checkmark$ \\
Gapping & $\checkmark$ \\
\hline
\end{tabular}

GAPPING is the most usual way to relativise an argument in Wobzi. The gap is created with the clausal nominalisation of the relative clause. The gapped function is indicated by the nominalising enclitic (see Table 5 ) used in the relative clause. As shown in Example (13), the head nouns are not repeated in the relative clause, creating a gap in the position they should have been.
a. $k æ t \varphi \check{z}=\chi t \epsilon^{h} \partial r=j i$
$\left[{ }_{i}\right.$ nə-ré $\left.=p a\right]$
$j d \hat{\partial}_{i}=$ zæresitə
pickled.vegetable $=$ sour $=$ GEN $\varnothing$ PFV-be.left ${ }_{2}=$ NMLZ:S water $=$ and

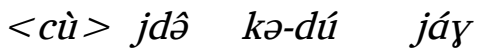
vinegar water INF-pour can $_{1}$
The liquid that is left by making the pickled vegetable can be poured away.

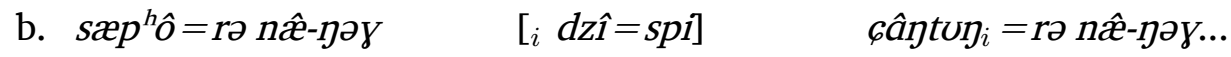
tree $=$ TOP IPFV.PST.Q-be ${ }_{2} \varnothing$ eat $_{1}=$ NMLZ:P.IRR fruit $=$ TOP IPFV.Q-be ${ }_{2}$
Whatever it was, trees or edible fruits...

The NON-REDUCTION STRATEGY is used in internally-headed relative clauses, with the head noun present within the relative clause itself and, the PRONOUN RETENTION STRATEGY can sometimes be found in correlative constructions. Example (14a) shows an internally-headed relative with the non-reduction strategy, in which the head noun occurs in the relative clause; Example (14b) presents a correlative construction, in which a resumptive pronoun, ætâ, occurs in the main clause, hence the PRONOUN RETENTION STRATEGY.

a. Non-reduction

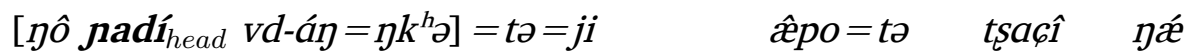
1SG child see $_{2}-1 \mathrm{SG}=\mathrm{NMLZ}: \mathrm{P}=\mathrm{DEF}=\mathrm{GEN}$ father $=\mathrm{DEF}$ Bkrashis be ${ }_{1}$ The father of the child I saw is Bkrashis.

b. Pronoun retention

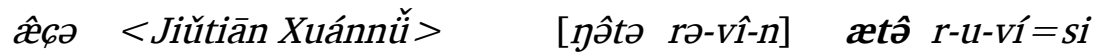
CONJ Goddess.of.the.Nine.Skies which IMP-do ${ }_{1}-2$ DEM PST-INV-do ${ }_{2}=$ IFR He did what the Goddess of the Nine Skies told him to (literally: What the Goddess of the Nine Skies asked him to do, he did it). 


\subsection{Place of the head noun}

The head noun of a relative construction in Wobzi can occur either inside or outside the relative clause. When it is outside, it can either precede or follow the relative clause.

\subsubsection{Externally-headed relative}

More often than not, the head noun occurs outside the relative clause in Wobzi Khroskyabs. Both prenominal and postnominal head-external relatives are attested, as shown in (15), however, prenominal relatives are by far the dominant type.

a. Prenominal

[i $\chi$ tolú mnây $\chi$ tó $=p a] \quad$ molé $e_{i}$ k-u-smê $=s i$

$\varnothing$ hat red wear(hat $)_{1}=$ NMLZ:A girl PST-INV-name ${ }_{2}=$ IFR

They called her the girl who wore a red hat.

b. Postnominal

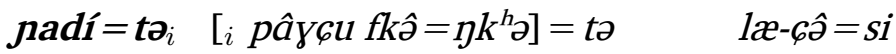

child $=$ DEF $\varnothing$ pear $\quad$ steal $_{1}=$ NMLZ:A $=$ DEF PST- $\mathrm{gO}_{2}=\mathrm{IFR}$

The child who stole the pears walked away.

c. Postnominal

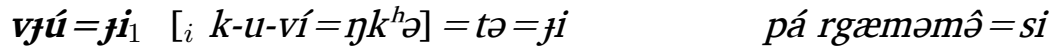

man $=$ PL $\varnothing$ PST-INV-do ${ }_{1}=$ NMLZ:P $=$ DEF $=$ PL all be.naked $_{1}=\mathrm{IFR}$

The humans that she made were all naked.

The postnominal relative clause in (15b) is unambiguous, however Example 15c can be alternatively interpreted as a head-internal relative (we will see ambiguous constructions in $19 \mathrm{~b}$ and 21 in Section 3.3.3). In (15b), the argument relativised is a third person A, which, in a normal clause, must be followed by an ergative marker, as shown in (16).

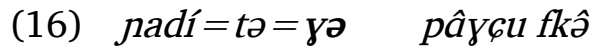

child $=$ DEF $=$ ERG pear $\quad$ steal $_{1}$

The child steals pears.

\subsubsection{Headless relative}

Headless relatives are the most common type found in Wobzi, illustrated in (17). The relative clause itself is identical to head-external relatives, however the head noun is omitted in the main clause.

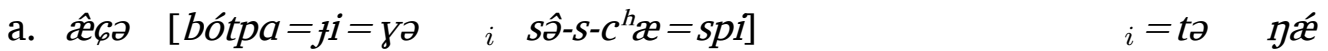
CONJ Tibetan $=$ PL $=$ ERG $\varnothing$ SUPERL-CAUS-be. big $_{1}=$ NMLZ:P.IRR $\varnothing=$ DEF be $_{1}$ This is something the Tibetans admire the most.

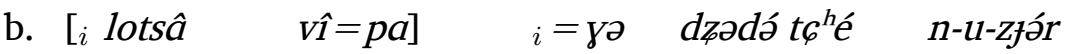
$\varnothing$ translation do $_{1}=$ NMLZ:A $\varnothing=$ ERG letter religion PST-INV-translate ${ }_{2}$ The interpreter (he who translates) translated the Buddhist texts. 


\subsubsection{Internally-headed relative}

Head-internal relatives are rare in Wobzi, unlike the case in Japhug, where most Srelativisations are internally-headed (Jacques 2016b).

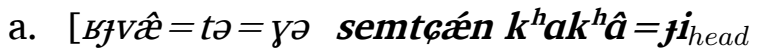

fox $=\mathrm{DEF}=\mathrm{ERG}$ animal other $=\mathrm{PL}$

$\left.k-u-r d u ́=s i=\eta k^{h} \partial\right]=f i=t \partial=y \partial \quad n \hat{u}$ sô $\eta \not \dot{x}-n u-r \hat{\partial}$

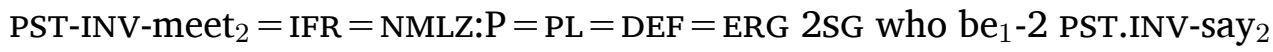

The other animals that he met asked, "Who are you?"

b. $\left[j \hat{e}=y \partial \quad\right.$ vfú $\left.u-t^{h} \dot{o}=\eta j k^{h} \partial=t \partial=f i\right]=d \partial$

3SG $=$ ERG man PST.INV-build ${ }_{2}=$ NMLZ:P $=\mathrm{DEF}=\mathrm{PL}=$ also

$n æ-m æ-n d z \underline{a}=s i$

IPFV.PST-NEG 2 -be.identical ${ }_{2}=$ IFR

The men that she created were not identical as well.

The internal heads of the examples in (18) are the P's of the predicate of the relative clause, while internally-headed relatives also occur with the relativisation of the ditransitive $\mathrm{T}$ (although it can be seen as a variant of $\mathrm{P}$ ) and, ambiguously, the intransitive S.

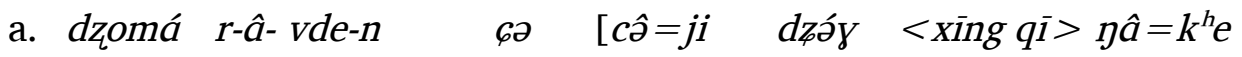
Sgrolma NPST-IRR-See ${ }_{1}-2$ CONJ $3 S G=$ GEN before week $\quad 1 \mathrm{SG}=\mathrm{ABL}$

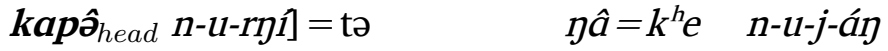

book PST-INV-borrow ${ }_{2}=$ DEF $1 \mathrm{SG}=$ DAT IMP-INV-return ${ }_{1}-1 \mathrm{SG}$

$æ-r æ ́-n=n i$

IMP-Say $_{1}-2=$ ASSRT

If you see Sgrolma, tell her to return the book that she borrowed from me last week.

b. $\left[\right.$ semtçæ $_{\text {head }} s \hat{a}=t^{h} a \quad$ ndżvôa $\left.=p a\right] \quad u-s q^{h} l i ́$

animal earth $=$ LOC walk $_{1}=$ NMLZ:S PST.INV-let.out $_{2}$

She created animals that walked on the earth.

Example (19b), however, can be alternatively analysed as a postnominal externallyheaded relative, with the structure below:

(20) semtçæn $_{i}\left[i\right.$ sâ $\left.=t^{h} a \quad n d z ə v a \hat{a}=p a\right] \quad u$-sqh ${ }^{h} l i ́$

animal $\varnothing$ earth $=$ LOC walk $_{1}=$ NMLZ:S PST.INV-let.out ${ }_{2}$

She created animals that walked on the earth.

The ambiguity is also found in P-internal relatives without the A of the predicate of the relative clause being overt, as in (21). Notice the difference in meaning between (21a) and (21b).

(21) a. Head-internal interpretation 


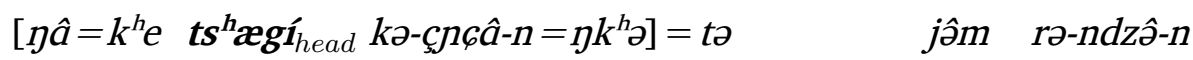

$1 \mathrm{SG}=\mathrm{ABL}$ clothes $\quad$ PST-take. back $_{1}-2=$ NMLZ:P $=$ DEF home IMP-bring ${ }_{3}-2$

Take the clothes that you took back from me home.

b. Head-external interpretation

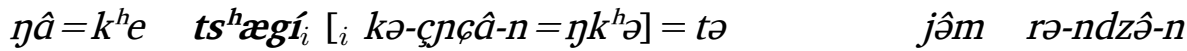

$1 \mathrm{SG}=\mathrm{DAT}$ clothes $\varnothing$ PST-take.back $1-2=$ NMLZ:P $=$ DEF home IMP-bring ${ }_{3}-2$

Bring me home the clothes that you took back.

As Mazaudon (1978: 402) notices, in Tibetan as well, if the head noun is an intransitive $\mathrm{S}$ or a transitive $\mathrm{P}$ (A unexpressed), it is impossible to determine the type of the relative clause, a head-internal one or a postnominal one.

Other Trans-Himalayan languages that exhibit head internal relatives seem also to restrict the possible functions of the head noun to a certain set. In Mongsen Ao, head internal relatives are restricted to a notional core argument of a bivalent verb, which is, in the example provided by Coupe (2017), a T argument:

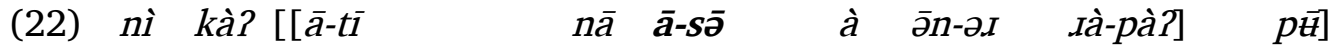
1sG also VOC-elder.sibling AGT NRL-shawl one take-SEQ come-NMLZ PROX

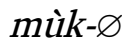

wrap-PST

I also wore this shawl that Elder Sister brought.

In Belhare (Van Valin and LaPolla 1997: 304; Bickel 2004), amongst the rare examples of head-internal relatives, the distribution of arguments that can be relativised are exactly the same as in Wobzi Khroskyabs, restricted to S, P and T, as shown in (23).
a. [ma?i head $_{\text {khiu-1-na] }}$
misen
niu-t-u-ga
$i$
human quarrel-NPST-DET acquaintance know-NPST-3sgU-2sgA $Q$
Do you know the person who is quarrelling?

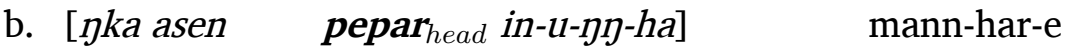
1SG yesterday cigarettes buy-3sgU-1sgA-NMLZ finish-TEL-PST
The cigarettes that I bought yesterday are used up.
c. [asenle paisa ${ }_{\text {head }}$ mai-khut-piu-sa-ha] n-chitt-he before money 1sgU-steal-BEN-TRANS.PERF.-NMLZ 3nsgA-find-PST They found the money that he stole from me.

In Tibetan, similarly, as DeLancey (1999: 242) points out, pure internally-headed relatives are especially common with the relativisation of objects.

Works on internally-headed relatives such as Williamson (1987: 169) and Basilico (1996: 526), etc. show that definite marking is generally forbidden on the head of internally-headed relative clauses, while indefinite marking is not.

Williamson (1987: 171) cites the Lakhota definite marker $k i$ cannot be added to the head within an internally-headed relative: 
(24) a. [[Mary [owįža wą] kağe] ki/cha/k'ụ he ophewatụ Mary quilt one make $\mathrm{DEF}_{1} / \mathrm{un}_{\mathrm{DEF}} \mathrm{DEM}$ buy.1SG I bought the quilt that Mary made.

b. *[[Mary [owįža ki] kağe] $\mathrm{ki}$ he ophewatụ Mary quilt DEF make DEF 1 DEM buy.1SG

This constraint is true for Wobzi Khroskyabs. The definite marker $=$ to cannot appear on the head of an internally-headed relative clause. To illustrate this constraint, we may, for instance, modify the sentence in (18b), as shown in (25). The modified example (25a) is ungrammatical, with the head noun vfú 'man' marked by the definite marker $=t$. That an internal head cannot take definite marking does not mean it is not semantically definite, on the contrary, many internal heads are semantically definite, including our original example (18b). If the head noun is semantically indefinite, one is free to add an indefinite marker such as rây 'one' behind it, as in (25b).

a. $*\left[j \hat{e}=y \partial \quad \boldsymbol{v} \boldsymbol{\jmath} \dot{u}=\boldsymbol{t}_{\text {head }} u-t^{h} \boldsymbol{O}=\eta k^{h} \partial\right]=t \partial=f i=d \partial$

$3 \mathrm{SG}=\mathrm{ERG}$ man $=\mathrm{DEF} \quad$ PST.INV-build ${ }_{2}=\mathrm{NMLZ} \mathrm{P}_{2}=\mathrm{DEF}=\mathrm{PL}=$ also

$n æ-m æ-n d z \underline{a}=s i$

IPFV.PST-NEG 2 -be.identical $2=$ IFR

b. [jê=yə vłú rấyhead $\left.u-t^{h} \boldsymbol{o}=\eta k^{h} \partial\right]=d \partial$

3SG $=$ ERG man one $\quad$ PST.INV-build ${ }_{2}=$ NMLZ: $_{2}=\mathrm{DEF}=\mathrm{PL}=$ also

$n æ-m æ-n d z \underline{a}=s i$

IPFV.PST-NEG 2 -be.identical $2=$ IFR

A man that she made was also not identical.

\subsection{Indexation in relative clauses}

In externally-headed relatives that relativise core arguments as well as the $\mathrm{R}$ of ditransitive constructions, the gap left in the relative clause is considered as the third person, no matter whatsoever person the head noun refers to.

(26) $S$

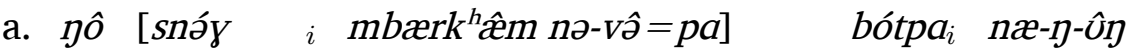

1SG yesterday $\varnothing$ 'Barkhams PST-go ${ }_{2}=$ NMLZ:S Tibetan IPFV.PST-be ${ }_{2}-1 \mathrm{SG}$

I am the Tibetan that went to 'Barkhams yesterday.

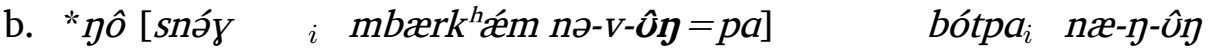

1SG yesterday $\varnothing$ 'Barkhams PST-go ${ }_{2}-1 \mathrm{SG}=$ NMLZ:S Tibetan IPFV.PST-be ${ }_{2}-1 \mathrm{SG}$

In Example (26b), even though the $S$ of the matrix clause is 1st person singular, it is ungrammatical, because the verb in the relative clause takes the 1SG ending.

(27) $A$ 


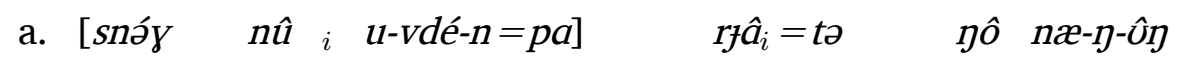
yesterday $2 \mathrm{SG} \varnothing \mathrm{INV}-\mathrm{see}_{2}-2=$ NMLZ:P Chinese $=$ DEF $1 \mathrm{SG}$ IPFV.PST-be ${ }_{2}-1 \mathrm{SG}$ I was the Chinese that saw you yesterday.

b. [*snór nû̀ ${ }_{i}$ vdé-n=pa] $r f \hat{a}_{i}=t \partial \quad \eta \hat{o} \quad n æ-\eta-\hat{o} \eta$ yesterday 2SG $\varnothing$ see $_{2}-2=$ NMLZ:P Chinese $=$ DEF 1 SG IPFV.PST-be 2 -1SG

The obligatory use of the inverse marking in (27a) shows clearly that the gap must be 3rd person. Since the $\mathrm{S}$ of the matrix clause is 1st person singular, that ranks higher than 2nd person singular in the empathy hierarchy, the inverse should not have appeared in this $1 \rightarrow 2$ scenario.

Examples with $\mathrm{P}$ and $\mathrm{R}$ relativisations are shown in (28) and (29).

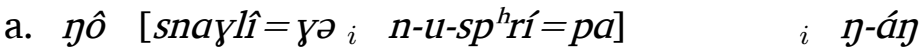

1SG moon $=$ ERG $\varnothing$ PST-INV-send ${ }_{2}=$ NMLZ:P $\varnothing$ be $_{1}-1$ SG

I am someone sent by the moon.

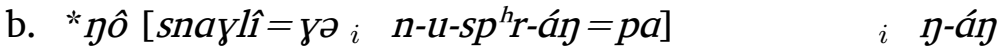

1SG moon $=$ ERG $\varnothing$ PST-INV-send ${ }_{2}-1 \mathrm{SG}=$ NMLZ:P $\varnothing$ be $_{1}-1$ SG

(29) $R$

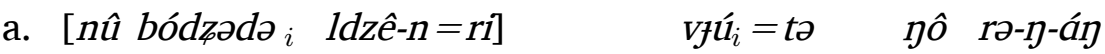

2sG Tibetan $\varnothing$ teach $_{1}-2=$ NMLZ:Obl person $=$ DEF 1 SG NPST-be ${ }_{1}-1$ SG I am the one to whom you teach Tibetan.

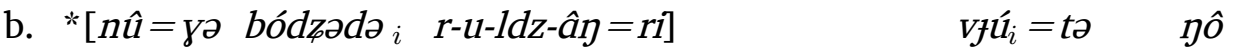
2SG $=$ ERG Tibetan $\varnothing$ NPST-INV-teach ${ }_{1}-2=$ NMLZ:Obl person $=$ DEF 1 SG

rə-ク-án

NPST-be $1-1 \mathrm{SG}$

\section{Nominalised relative clause}

Except for a few languages that seem to have developed European-like relative pronouns (Mongsen Ao, for instance, see Coupe 2007: 134), nominalisation is a typical way to form relative clauses in Trans-Himalayan, which is either studied for individual languages, such as Sun and Lin (2007), Sun (2006), Jacques (2016b) on Rgyalrongic languages, Bickel (1999) and Lahaussois (2002) on Kiranti languages, LaPolla (2008) on Rawang, Matisoff (1972) on Lahu, or in typological accounts such as Genetti et al. (2008) presenting data from five Tibeto-Burman branches. Nominalisation as a relativising device has therefore been noticed by many researchers, Bickel (1999) coins the term STANDARD SINO-TIBETAN NOMINALISATION, and DeLancey (2002) calls it RELATIVISATION-NOMINALISATION SYNCRETISM.

Wobzi Khroskyabs is no exception to this generality. Nominalisation is undoubtedly the most frequent way of relativisation. In Table 5 in Section 2.3, I have already listed the nominalisers used for relative clauses, and in this section, we will have a close look at some examples and uses, focusing on head-external relatives. 


\subsection{S, A and possessor}

The relativisation of $\mathrm{S}, \mathrm{A}$ and possessor invariably makes use of the markers $=p a$ and $=\eta k^{h}$. The difference between the two markers are subtle and ignorable, they are almost always interchangeable.

The sentences in Example (30) show the relativisation of S. In (30a), we have an S-relativisation with the marker $=p a$, and in (30b) with the marker $=\eta k^{h}$. Note that the finiteness of the bare verb form yôr 'to help' in (30a) is impossible to determine, while the form $n \partial-t^{h}{ }^{\prime}$ (PST-arrive 2 ) is clearly finite, with the Stem 2 of the verb.

\section{S-relativisation}

a. $=p a$

$$
j \hat{e}=j i \quad\left[v^{\prime} c^{h} \hat{a}=t^{h} a \quad i \quad \gamma \hat{\partial} r=p a\right] \quad n æ-\eta \hat{\partial} \gamma=s i
$$

3SG $=$ GEN lower.part $=$ LOC $\varnothing$ help $1=$ NMLZ:S IPFV.PST-be ${ }_{2}=$ IFR

It was his servant (literally: It was someone under his reign that assisted him).

b. $=\eta k^{h}$ o

$$
\begin{aligned}
& \text { [i rłâægær nə-thó } \left.=\eta k^{h} \partial\right] \quad m k^{h} \hat{\gtrless}=p a_{i} \quad r \nmid \hat{x} g æ r=j i \\
& \varnothing \text { India } \quad \text { PST-arrive }{ }_{2}=\text { NMLZ:S be.expert }{ }_{1}=\text { NMLZ:S India }=\text { GEN } \\
& \text { pĥntsota }=f i=t ə=\gamma \partial \quad \hat{x} v a \gamma \text { âmni } m k^{h} \hat{x} \quad \text { rây }=\text { tə nêffi } \\
& \text { Pandita }=\mathrm{PL}=\mathrm{DEF}=\text { ERG INTERJ like.this be.expert }{ }_{1} \text { one }=\mathrm{DEF} 2 \mathrm{PL} \\
& n æ-N q^{h} a r \eta \hat{a}-n=s i \quad u-r \hat{z}=p a \\
& \text { PST-expel }{ }_{2}-2=\text { IFR PST.INV-say }{ }_{2}=\text { NMLZ }
\end{aligned}
$$

The noblemen, the Paṇditāhs that came from India said, "Helas! You expelled such an intelligent person!"

The examples in (31) show the relativisation of the A in Wobzi. The structure is similar to that of the S.

\section{A-relativisation}

a. $=p a$

çsæ̂rpa $\hat{x} m o=$ to $\quad[i<$ <íng guǒ> nsyó=pa $] \quad$ æmâ $c^{h} \mathfrak{x}_{i}$

be.new mother $_{1}$ DEF $\varnothing$ apple $\quad$ sell $_{1}=$ NMLZ:A old.lady

$æ-$ - jјæví $=s i$

PST-pretend $\mathrm{d}_{2}=$ IFR

The step mother disguised herself as an old woman that sold apples.

b. $=\eta k^{h} \partial$

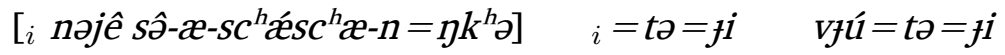

$\varnothing$ 2SG PROG-NPST-flatter ${ }_{1}$ NMLZ:A $\varnothing=\mathrm{DEF}=\mathrm{PL}$ man $=\mathrm{DEF}=\mathrm{PL}$

$r-\hat{a}-v j i \quad x t \hat{\partial}=f i=\gamma \partial \quad n \hat{u} \quad \hat{a}-d \not \partial \partial \not \xi \partial-n=t s^{h} i$

NPST-JUSS-come ${ }_{1} 3 \mathrm{SG}=\mathrm{PL}=$ ERG 2 SG NPST.JUSS-pull $\mathrm{L}_{2}-2=\mathrm{IFR}$

Just let those who like to flatter you the most come and pull you out! 
The possessor, ranked low in the Accessibility Hierarchy and often considered a peripheral argument, makes use of the same markers for the $S$ and the A when relativised, as shown in (32). As Sun (2006) points out for Tshobdun, which shows the same phenomenon, possessor relativisation with the same marker for the $S$ or the A may be related to possessor raising. Possessor raising is attested only in constructions of which the possessee is physically or mentally related to the possessor (e.g. body parts, sentiments), requiring that the verb index the possessor instead of the possessee, which should have been indexed (Lai 2015).

\section{Possessor relativisation}

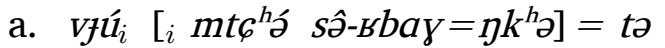
BNd $\hat{x}=s p i$ man $\varnothing$ mouth SUPERL-be.many ${ }_{1}=$ NMLZ:Poss $=$ DEF be. popular $_{1}=$ NMLZ mí not.exist 1 People who are verbose are not popular (literally: people whose mouths are many are not popular).

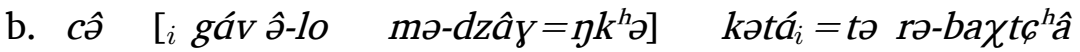
DEM $\varnothing$ leg one-CL NEG -exist $_{1}=$ NMLS dog $=$ DEF NPST-be.poor ${ }_{1}$ The dog that lost one of its legs is so poor (literally: the dog of which one of the legs is not there is so poor).

\section{$4.2 P$}

The relativisation of the $\mathrm{P}$ in Wobzi Khroskyabs shows different patterns from Rgyalrong languages. Modality plays the determinative role in the choice of the nominaliser. The nominaliser $=s p i$ is used in irrealis, more precisely, deontic or epistemic modalities, and $=p a$ or $=\eta k^{h}$ a are used in all realis modalities ${ }^{5}$.

The examples in (33) illustrate the usage of the nominaliser $=$ spi.

Morphology-wise, the nominaliser $=s p i$ marks verb forms in Stem 1, and is the only relativising nominaliser attested to be attached to explicitly marked infinitive forms. The bare verbs in (33a) and (33b) are uncertain in terms of finiteness; the verb form 1-u-stî (NPST-INV-put ${ }_{1}$ ) is finite, given the presence of the inverse marker $u-$; the example (33d) shows an infinitive verb form marked by the nominaliser $=s p i, k ə-t s h \hat{\partial}$ (INF-hit ${ }_{1}$ ), because the inverse marker $u$-is not employed in the presence of an orientational prefix $\mathrm{k} \partial$-.

Modality-wise, the use of $=s p i$ adds to the relative clause a deontic or epistemic flavour, and is better translated in English with "thing to do", "that ought to..." or "that should...", etc. Example (33a) indicates a participant-internal possibility (van der Auwera and Plungian 1998: 80) that the fruits are edible; in (33b), the marker $=s p i$ conveys a deontic meaning in that the thing in question should be used when building a house; in Example (33c), the relative construction can be either be interpreted as deontic, "something that Tibetans ought to offer", or epistemic, " something that Tibetans may or would offer". The same case is found in (33d), which allows both irrealis readings.

\footnotetext{
${ }^{5}$ I owe this idea to Gong Xun.
} 
$=s p i$

a. $\left[{ }_{i} d z \hat{\imath}=s p i\right] \quad \quad 6 \hat{a} \eta t u \eta_{i}=r \partial n \hat{x}-\eta \partial \partial$

$\varnothing$ eat $_{1}=$ NMLZ:P.IRR fruit $=$ TOP IPFV.PST.Q-be ${ }_{2}$

Whether they are edible fruits (literally: whether they are fruits to eat)

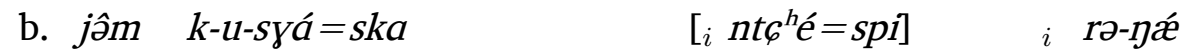
house NPST-INV-build ${ }_{1}=$ NMLZ:time $\varnothing$ use $_{1}=$ NMLZ:P.IRR $\varnothing$ NPST-be $_{1}$ This is something to use when building a house.

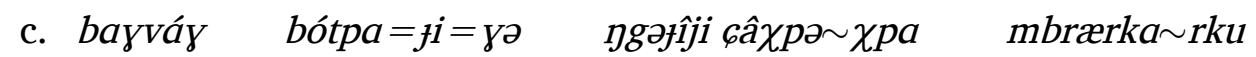
barley. wine Tibetan $=\mathrm{PL}=$ ERG CONJ friend $\sim$ GENERIC relative $\sim$ GENERIC rə-tô $=s k a \quad\left[{ }_{i} l-u-s t \hat{i}=s p i\right] \quad$ rây $\eta \not ́$ NPST-arrive ${ }_{1}=$ NMLZ:Time $\varnothing$ NPST-INV-put $_{1}=$ NMLZ:P.IRR one be $_{1}$ The Tibetan barley wine is something that Tibetans would offer to their friends and relatives when they come to visit.

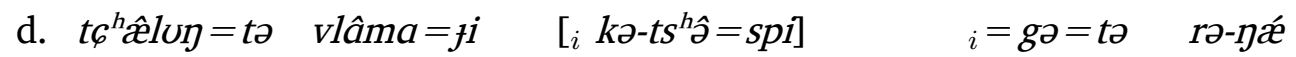
cymbal $=$ DEF big.monk $=$ PL $\varnothing$ INF-hit $_{1}=$ NMLZ:P.IRR $\varnothing=\mathrm{CL}=$ DEF NPST-be $_{1}$ The cymbal is something for the big monks to play.

When it comes to the realis modality, the $\mathrm{P}$ is relativised in the same way as the $\mathrm{S}$, the A and the possessor, with the markers $=p a$ or $=\eta k^{h}$, examples are shown in (34). The verb form of the relative clause can be in either Stem 1, as in (34a), or Stem 2, as in (34b) and $(34 c)$.

$=p a /=\eta k^{h} \partial$

a. $c \hat{\partial} \quad k a p \hat{\partial}=t \partial=g \partial \quad\left[\eta \hat{o}_{i} \quad n d-\hat{a} \eta=\eta k^{h} \partial\right] \quad<w e ́ n z h a ̄ n g>_{i}$ $\mathrm{DEM}$ book $=\mathrm{DEF}=\mathrm{LOC} 1 \mathrm{SG} \varnothing$ like $_{1}-1 \mathrm{SG}=\mathrm{NMLZ}: \mathrm{P}$ article

$\hat{\partial}-1 o=d \partial \quad m i ́$ one-CL $=$ also not.exist 1

There is not a single article that I like in this book.

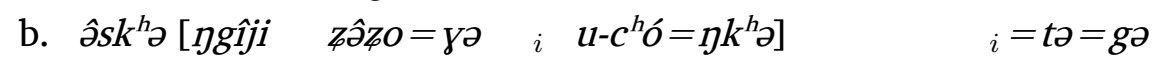

now 1PL.GEN uncle $=$ ERG $\varnothing$ PST.INV-open ${ }_{2}=$ NMLZ:P $\varnothing=\mathrm{DEF}=\mathrm{LOC}$

$n t \varphi \hat{u}=\varphi i \quad$ nfê

work $_{1}=$ CONJ EXIST 1

Now, he works in the shop opened by my uncle.

c. $\eta \hat{o} \quad\left[s n a y l \hat{\imath}=\gamma^{\partial}{ }_{i} \quad n-u-s p^{h} r i ́=p a\right] \quad i \quad \eta$-án

$1 \mathrm{SG}$ moon $=$ ERG $\varnothing$ PST-INV-send ${ }_{2}=$ NMLZ:P $\varnothing$ be $_{1}-1$ SG

I am someone sent by the moon.

Since the relativisation of the $\mathrm{P}$ in realis situations shares the same markers with that of the $\mathrm{S}$ and the A, one may concern about ambiguity that might occur in those constructions. However, with verb forms indexing first and second persons, there would not be any ambiguity. In (34a), $n d-\hat{a} \eta=\eta k^{h}$ ( (like ${ }_{1}-1 \mathrm{SG}=$ NMLZ:P) is unambiguously a case of P-relativisation, even when taken out of its original semantic context, and without the A ( $\eta \hat{o}$ ' $1 \mathrm{SG}^{\prime}$ ') overtly present. If it were an A-relativisation of a third person A, i.e. "the one that likes me", an inverse marker must be added: 


$$
\begin{aligned}
& u-n d-\hat{a} \eta=\eta k^{h} \partial \\
& \text { INV-like }{ }_{1}-1 S G=\text { NMLZ:A } \\
& \text { the one that likes me }
\end{aligned}
$$

It cannot be an A-relativisation of first person, either, since I mentioned in Section 3.4, that the relativised argument is treated as third person in the relative clause. A relative clause referring to the first person is illustrated in (36).

$$
\begin{aligned}
& {\left[n d \hat{x}=\eta k^{h} \partial\right] \quad \eta \text {-án }} \\
& \text { like }_{1}=\text { NMLZ:A be }{ }_{1}-1 \mathrm{SG} \\
& \text { I am the one that likes it. }
\end{aligned}
$$

When the verb form of the relative clause is in third person, ambiguity will arise if no argument is present. Take the relative clause of (34b) as an example. If the A, zôzo 'uncle' were not present, the form $u-c^{h} \delta=\eta k^{h} \partial$ (PST.INV-open ${ }_{2}=$ NMLZ) would have two contradicting meanings, either "the one who opened" or "the thing that she/he opened".

\subsection{Instrument and place}

Place and instrument adjuncts are relativised with the oblique nominaliser $=r i$. Place relativisation is illustrated in (37). Note that the marker $=r i$ is attached to the inferential marker $=s i$ in (37b), instead of directly to the finite verb, which indicates a clausal nominalisation.

\section{(37) Place relativisation}

a. $t^{h} æ \eta \hat{\partial} m[i j b \hat{\partial} v=r i] \quad i=t \partial=t^{h} a \quad j b \hat{\partial} v=r i=t^{h} a$

illness $\varnothing$ swell $_{1}=\mathrm{NMLZ:Obl} \varnothing=\mathrm{DEF}=\mathrm{LOC} \mathrm{swell}_{1}=\mathrm{NMLZ}: \mathrm{Obl}=\mathrm{LOC}$

$<$ miánhuā > = tə $k^{h} \hat{u}=s i$

cotton $=$ DEF $\quad$ put.in ${ }_{1}=$ IFR

One puts cotton on the place where it is swollen.

b. cha [jôm i næ-bó $\left.n æ-k^{h} r \hat{\partial}=s i=r i\right]$

DEM house $\varnothing$ NPST-fall 1 IPFV.PST-be.about.to ${ }_{2}=$ IFR

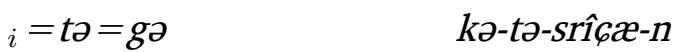

$\varnothing=$ NMLZ:Obl $=\mathrm{DEF}=$ LOC IMP-NEG 4 -go.to.look $1-2$

Don't go to see the place where the house is about to collapse.

Instrument relativisation is illustrated in (38a), with example (38a) presenting a bare verb, of which the finiteness cannot be determined, and example (38b) a finite verb.

(38) Instrument relativisation

a. [ ${ }_{i}$ s dojú $\left.^{h}{ }^{h} \mathscr{z}=r i\right] \quad$ lá $y_{i}$ u-ndzé $=s i$

$\varnothing$ fish take $_{1}=$ NMLZ:Obl stick PST.INV-get ${ }_{2}=$ IFR

He got a stick that was used to catch fish.

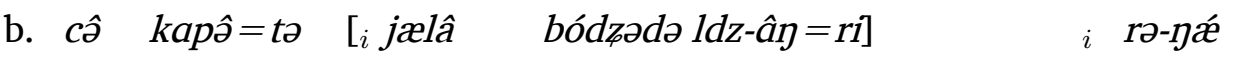
DEM book $=$ DEF $\varnothing$ specially Tibetan learn $_{1}-1 \mathrm{SG}=$ NMLZ:Obl $\varnothing$ NPST-be This book is my tool of learning Tibetan. 


\subsection{Time}

Wobzi developed two markers for Time relativisation presenting no semantic distinction, $=s k a$ and $=l_{u \eta} k^{h} a$. Only headless relatives are found.

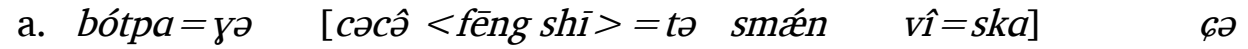
Tibetan $=$ ERG DEM rheumatism $=$ DEF medecine do $_{1}=$ NMLZ:Time CONJ

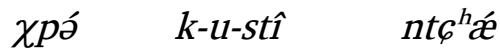
mugwort PST-INV-put ${ }_{1}$ will $_{1}$ When Tibetans treat rheumatism, they would use mugwort.

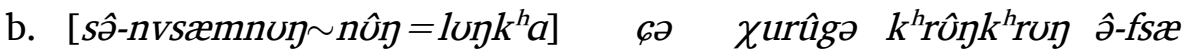
PROG-think $1 \sim$ PROG $=$ NMLZ:Time CONJ up.there white.crane one-CL $r \partial-f e ́=s i$ IPFV.PST-exist ${ }_{2}=$ IFR When they were thinking, the sky became filled with white cranes.

\subsection{Ditransitive constructions}

Although Wobzi exhibits two types of ditransitive constructions, indirective and secundative, the relativisation of their arguments does not follow these alignments.

The nominalisers used for T-relativisation are the same as those for P-relativisation, $=s p i$ for irrealis situations and $=p a /=\eta k^{h}$ ə for realis ones, and the nominaliser used for R-relativisation is the oblique $=r i$. Examples are illustrated in (40) and (41).

(40) T-relativisation

a. Indirective: $k^{h} \hat{a}$ 'to give'

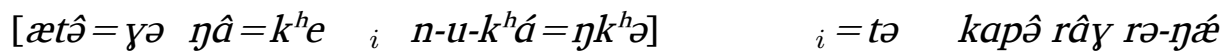
$3 S G=E R G 1 S G=D A T ~ \varnothing$ PST-INV-give ${ }_{2}=$ NMLZ:P $\varnothing=$ DEF book one NPST-be ${ }_{1}$ The thing that he gave me is a book.

b. Secundative: spi' to lend'

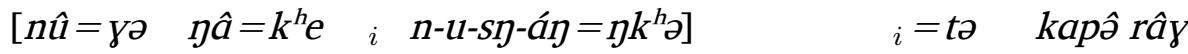

2SG $=\mathrm{ERG} 1 \mathrm{SG}=\mathrm{DAT} \varnothing \mathrm{PST}-\mathrm{INV}-\mathrm{lend}_{2}-1 \mathrm{SG}=\mathrm{NMLZ}: \mathrm{P} \varnothing=\mathrm{DEF}$ book one

$n æ-\eta \hat{\partial} y$

IPFV.PST-be 2

The thing he lent me was a book.

(41) R-relativisation

a. Indirective: ldzê 'to teach'

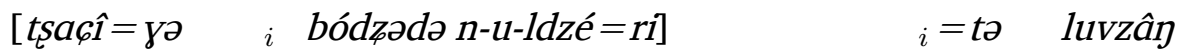

Bkrashis $=$ ERG $\varnothing$ Tibetan PST-INV-teach ${ }_{2}=$ NMLZ:Obl $\varnothing=$ DEF Blobzang

rə-ワǽ

NPST-be $_{1}$ 
The one to which Bkrashis taught Tibetan is Blobzang.

b. Secundative: bâ 'to give (food)'

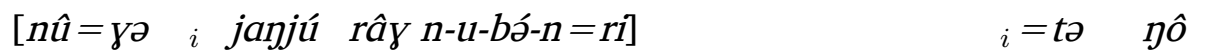

$2 \mathrm{SG}=\mathrm{ERG} \varnothing$ potato one PST-INV-give(food) $)_{2}-2=$ NMLZ:Obl $\varnothing=$ DEF $1 \mathrm{SG}$

$n æ-\eta-\hat{U} \eta$

NPST-be 1 -1SG

The one to which you gave a potato was me.

\section{Interim summary}

\subsection{Syntactic pivots}

In this section, I will focus only on the arguments entailed by each verb type, that is to say, $\mathrm{S}$ (intransitive verbs), A (transitive verbs), $\mathrm{P}$ (transitive verbs), $\mathrm{T}$ (ditransitive and indirect transitive verbs) and $\mathrm{R}$ (ditransitive verbs). Since the $\mathrm{P}$ and the $\mathrm{T}$ in Wobzi are relativised in two ways depending on the modality chosen, syntactic pivots of the nominalisers can be analysed in several manners. One can discuss the syntactic pivots of each nominaliser according to the modal category, which is illustrated in Tables 7 and 8.

We can see in realis constructions, a binary distinction that isolates the $\mathrm{R}$ is given. From the point of view of relativisation, the four arguments, S, A, P and T cannot be distinguished, showing a neutral alignment. In irrealis constructions, an accusative pivot is observed (as termed by Bickel 2004), where S and A are treated in the same way, opposing to $\mathrm{P}$ and $\mathrm{T}$. No matter which modal category we are in, $\mathrm{P}$ and $\mathrm{T}$ are impossible to distinguish.

Table 7: Realis syntactic pivots

\begin{tabular}{|c|c|c|}
\hline Nominaliser & Pivot & Flagging \\
\hline $\begin{array}{l}=p a /=\eta k^{h} \partial \\
=r i\end{array}$ & $\begin{array}{l}\mathrm{S}, \mathrm{A}, \mathrm{P}, \mathrm{T} \\
\mathrm{R}\end{array}$ & $\begin{array}{l}\text { No flagging or }=\gamma \partial \text { 'ERG' } \\
\text { typically }=k^{h} e \text { 'DAT' }\end{array}$ \\
\hline
\end{tabular}

Table 8: Irrealis syntactic pivots

\begin{tabular}{lll}
\hline Nominaliser & Pivot & Flagging \\
\hline$=p a /=\eta k^{h} \partial$ & $\mathrm{S}, \mathrm{A}$ & No flagging or $=\gamma \partial$ 'ERG' \\
$=s p i$ & $\mathrm{P}, \mathrm{T}$ & No flagging \\
$=r i$ & $\mathrm{R}$ & typically $=k^{h} e^{\text {'DAT' }}$ \\
\hline
\end{tabular}

Alternatively, pivots can be mapped without considering modality, but from a pure morphosyntactic point of view, illustrated in Table 9. Inverse marking is essential to 
the understanding of relative constructions with $=p a$ or $=\eta k^{h}$, especially when the predicate takes first or second person endings: when inverse is present, the pivot is the A, and when there is no inverse, the pivot is the P. If the predicate of the relative clause is in third person, the pivot can be either the A or the $\mathrm{P}$, if no argument is present.

Table 9: Pivots from a morphosyntactic view point

\begin{tabular}{l|ll}
\hline Pivot & Nominaliser & Morphosyntactic feature \\
\hline \multirow{2}{*}{$\mathrm{P}, \mathrm{T}$} & $=s p i$ & always \\
\cline { 2 - 3 } & $=p a /=\eta k^{h} \partial$ & $\begin{array}{l}\text { A overt } \\
\text { The verb indexes first/second person, but without inverse }\end{array}$ \\
\hline $\mathrm{A}$ & $=p a /=\eta k^{h} \partial$ & $\begin{array}{l}\text { P overt } \\
\text { The verb indexes first/second person, and with inverse }\end{array}$ \\
\hline $\mathrm{S}$ & $=p a /=\eta k^{h} \partial$ & intransitive verbs \\
\hline $\mathrm{R}$ & $=r i$ & ditransitive verbs, indirect transitive verbs \\
\hline
\end{tabular}

Internally-headed relatives, as we mentioned in Section 3.3.3, only S and P (or T) can be relativised in this way. Therefore, like Belhare (Bickel 2004), internally-headed relatives show an ergative pivot in Wobzi.

In conclusion, while internally-headed relatives in Wobzi clearly shows an ergative pivot, externally-headed relatives are divided according to the modality chosen. In realis situations, the core arguments, excluding the $\mathrm{R}$, are treated in the same way, with the nominalisers $=p a$ or $=\eta k^{h}$. In irrealis situations, an accusative pivot is found, in which the $S$ and the $A$ are treated in the same way.

\subsection{Comparative remarks}

In this section, I will mainly focus on the comparison of the relativising nominalisers within Rgyalrongic languages and their origins.

\subsubsection{Overview of the nominalisers}

Among Rgyalrongic languages, there are basically two types of nominalising morphology. The first and possibly the indigenous type is found in Rgyalrong languages with nominalising prefixes that form participles serving as relative clauses. The prefixes from Japhug (Jacques 2008, 2016b) and Tshobdun (Sun 2006) are illustrated in Table 10, and examples are shown in (42), (43) and (44). Unlike Khroskyabs, relativisation in Rgyalrong has nothing to do with modality and the relativisation of the R (indirective); the instrument, the place and the time share the same prefix. 
Table 10: Nominalisers in Rgyalrong languages

\begin{tabular}{lll}
\hline Japhug & Tshobdun & Function \\
\hline \hline$k u{ }^{-}$ & $k \partial^{-}$ & S/A \\
\hline$k \gamma^{-}$ & $k e^{-}$ & $\mathrm{P}$ \\
\hline$s \gamma^{-}$ & $s e^{-}$ & Oblique \\
\hline
\end{tabular}

(42) Japhug

a. S/A

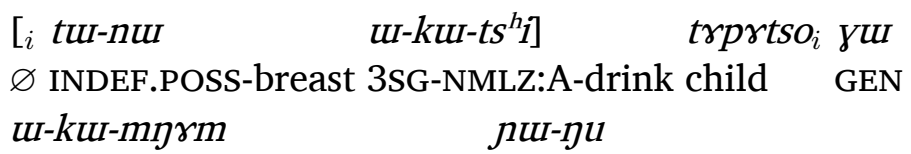

3SG.POSS-NMLZ:S-be.painful TESTIM-be

It is a disease of children who drink milk from the breast. (Jacques 2016b: 9)

b. $\mathbf{P}$

$\left[\begin{array}{ll}a_{i} O_{i} & a-m \gamma-k \gamma-s u z\end{array}\right] \quad$ trjmr $\gamma_{i}$ nu $k \gamma-n d z a m \gamma-n a z-a$

1SG $\varnothing$ 1SG-NEG-NMLZ:P-know mushroom DEM INF-eat NEG-dare-1SG

I do not dare to eat the mushrooms that I do not know. (Jacques 2016b: 10)

(43) Tshobdun

a. S/A

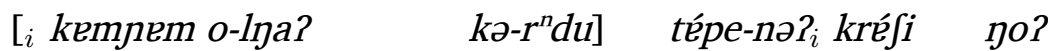

$\varnothing$ often 3SG.POSS-child NMLZ:A-hit father Bkrashis be

The father who hits his child so often is Bkrashis. (Sun 2006: 913)

b. $\mathbf{P}$

[kempem $\left._{i} \quad e-k e^{-}-t^{h} i\right] \quad$ nu tewa? me-ka

often $\quad \varnothing$ 1SG.POSS-NMLZ:P-drink DEF alcohol NON.EXIST-PART

I don't always have alcohol to drink. (Sun 2006: 913)

(44) a. Instrument (Japhug)

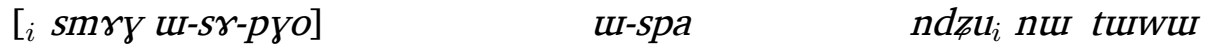

$\varnothing$ wool 3sG.POSS-NMLZ:Obl-twist 3sG.POSS-material stick DEF spindle

rmi

be.named

The stick used to twist wool is called the spindle. (Jacques 2008: 333)

b. Place (Tshobdun)

zo? [tóru $i_{i}$ o-se-tó] $\quad c^{h} o_{i} \quad \boldsymbol{e}$-le-tə-ne?

beef forage $\varnothing$ 3SG.POSS-NMLZ:Obl-EXIST 2 somewhere IRR-IMP-chase ${ }_{3}-2$

Lead the cattle to somewhere there is forage! (Sun 2006: 913) 
c. Time (Japhug)

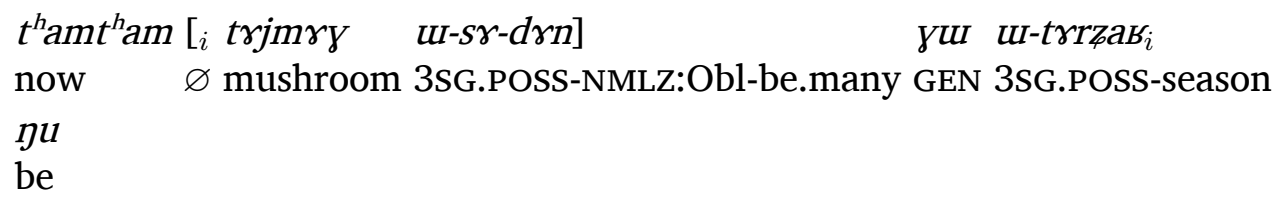

It is now the season mushrooms begin to multiply. (Jacques 2008: 334)

The second type of nominalising morphology concerns the combination of Khroskyabs and Horpa-Stau that make use of nominalising enclitics or suffixes. Relativisation in Horpa-Stau is yet to be fully understood, for the purpose of this section, I cite two of the outcomes of the ongoing investigation on Khang.gsar Stau, Jacques et al. (unpublished) and Jacques et al. (2017). Table 11 shows the nominalisers in this language.

Table 11: Nominalisers in Khang.gsar-Stau

\begin{tabular}{ll}
\hline Nominalisers & Function \\
\hline \hline$\eta k^{h} \partial$ & S/A \\
\hline$l \partial$ & $\mathrm{P}$ \\
\hline$r e$ & Oblique \\
\hline
\end{tabular}

In (45), examples of each nominaliser in Khang.gsar Stau are illustrated.

(45) Khang.gsar Stau

a. $\eta k^{h} \partial$

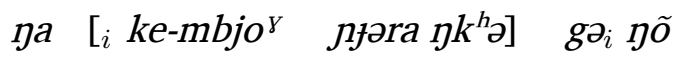

1SG $\varnothing$ very-be.fast run NMLZ:S CL be.1SG

I am someone that runs fast.

b. 10

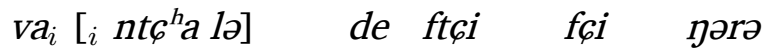

pig $\varnothing$ kill NMLZ:P DEF castrate should be.IFR

The pigs to be killed should first be castrated.

c. re

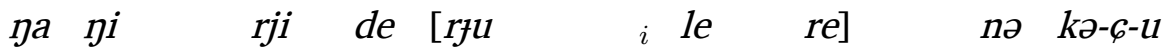

1SG 1SG.POSS horse DEF competition $\varnothing$ launch NMLZ:Obl LOC PFV-take-1SG

I was taken to the place where the horse race would take place.

Other Khroskyabs dialects present similar relativising strategies, while the nominalilsers may be different. Apart from Wobzi Khroskyabs, I conducted rough researches on the relativisation in 'Brongrdzong and Siyuewu Khroskyabs, both are very similar to Wobzi Khroskyabs. In Huang (2007) we can find a brief description of the very close Guanyinqiao dialect, and Yin (2007) has a short presentation on the relativisation of the Njorogs variant as well. Table 12 shows the nominalisers used in those dialects. 
Table 12: Nominalisers in Khroskyabs dialects

\begin{tabular}{llllll}
\hline Wobzi & Guanyinqiao & 'Brongrdzong & Siyuewu & Njorogs & Function \\
\hline \hline$=p a,=\eta k^{h} \partial$ & $=p a$ & $=p a$ & $=p a,=m \partial$ & $=p a,=m i$ & S/A/P \\
\hline$=s p i$ & $=s p i$ & $=s p ə$ & $=s p i$ & $=s p e$ & P.IRR \\
\hline$=s k a,=l v \eta k^{h} a$ & $=s k a$ & $=s k a$ & $=s k a,=$ reggon & $=$ to & Time \\
\hline$=r i$ & $=s c i$ & $=s c i$ & $=s c e$ & $=s t e$ & Oblique \\
\hline
\end{tabular}

All of the Khroskyabs dialects have pa-like nominalisers for the $\mathrm{S}$, the A and the realis $\mathrm{P}$, which is probably borrowed form the Tibetan agentive particle $\mathrm{T}^{\circ} p a$, however, the alternatives for this nominaliser vary from language to language. Siyuewu $=m ə$ and Njorogs $=m i$ should share the same Tibetan origin, वे' $m i$ 'man', Wobzi $=\eta k^{h}$ ə is identical to its equivalent in Khang.gsar Stau, which may again be borrowed from Tibetan वाबव' mkhan, originally meaning 'expert, skilful person', later as well an agentive particle.

The Khroskyabs dialects share the marker $=s p V$ for the irrealis $\mathrm{P}$. This marker is originally a noun meaning 'material', cognate to Japhug tr-spa 'material'. The original meaning is still in use in Modern Wobzi, as exemplified in (46).

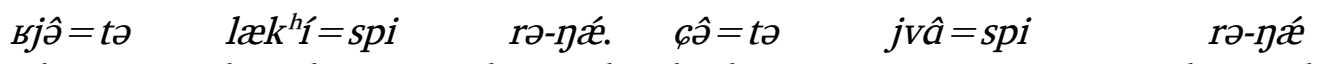
wheat $=\mathrm{DEF}$ bread $=$ material NPST-be $_{1}$ barley $=\mathrm{DEF}$ Tsampa $=$ material NPST-be $_{1}$

The wheat is the material of the bread, and the barley is the material of the Tsampa.

Khroskyabs alone developed distinctive markers for the time and the instrument/place, which are different from Rgyalrong languages and Stau. Most of the time nominalisers are again of Tibetan origin, =ska or =ska from Tibetan 취' skad 'moment', Wobzi $=l u \eta k^{h} a$ from Tibetan

= reggon from Tibetan ऐे२गण re.'gag 'sometimes'. The marker = to in Njorogs is however of unknown origin.

As for the instrument/place nominalisers, Guanyinqiao, 'Brongrdzong and Siyuewu share the marker $=s c V$, appearing as $=s c i$ or $=s c e$, while Wobzi $=r i$ is related to Khang.gsar Stau re.

\subsubsection{Modal distinction of the $P$}

All Khroskyabs dialects exhibit modal distinction regarding P-relativisation, using $=s p V$ to relativise the irrealis $\mathrm{P}$, and the same nominaliser for the $\mathrm{A}$ and the $\mathrm{S}$ to relativise the realis $P$. The feature, not found in any Rgyalrong language (but it can possibly be found in Horpa-Stau when more investigations are made), is attested in Modern Tibetan dialects.

Tibetan dialects developed different markers for this distinction, albeit described as an aspectual one between perfective and imperfective. In Central Tibetan, according to DeLancey (1999: 234-235), yag marks imperfective P-relativisation and pa marks perfective P-relativisation, as shown in (47).

(47) Central Tibetan

a. =yag (imperfective) 
[kho-s $\quad i \quad$ gsod=yag]-gi stag $_{i}$

3SG-ERG $\varnothing$ kill $=$ NMLZ-GEN tiger

the tiger that he will kill

b. $=p a$ (perfective)

[kho-s $\quad$ i gsod=pa]-'i stag $_{i}$

3SG-ERG $\varnothing$ kill $=$ NMLZ-GEN tiger

the tiger that he killed

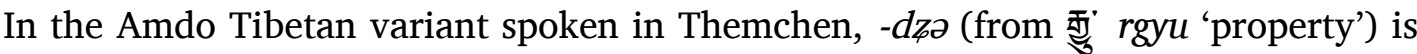
employed for imperfective P-relativisation, and -nu (or -ni/-nə) (from बे 'ni 'topic marker') for perfective P-relativisation (Haller 2004: 157-158):

(48) Themchen Amdo Tibetan

a. -dद्र (imperfective)

ә.лiya ta [i sa-dzə]-zəç-ra i mel-a

we.both now $\varnothing$ eat-NMLZ-INDEF-TOP $\varnothing$ not.exist-VOL.EVD

Both of us have nothing to eat now.

b. $-n u$ (perfective)

ndə jja $_{i}[i \phi \varphi i-n u]-y \partial \quad$ ko re

DEM yak $\varnothing$ slaughter-NMLZ-GEN fur be

This is the fur of the yak that you slaughtered.

\subsubsection{Prefixing relativisation/nominalisation in Khroskyabs}

The adoption of the Tibetan type of relativisation certainly decrease the original Rgyalrong type that makes use of prefixes. In Modern Khroskyabs, no prefixing relativisation/ nominalisation is found productive. Traces can be found at least with the oblique prefix $s$-, slightly mentioned in Section 2.3, is cognate to Rgyalrong $s V$ - and found in at least two examples, shown in (49). One of the examples concerns the nominaliser $=s p i$, which is related to the verb $v \hat{i}$ ' to do' with a lenified initial. In Rgyalrong languages, the cognate of vî 'to do' is pa 'to do' in Japhug, ka-pa in Cogtse Situ, and ka-viê in Bragdbar Situ' .

a. $s$-pi 'material (instrument of fabrication)' $\leftarrow v \hat{\imath}$ 'to do'

b. $s$ - $p^{h}$ ว́m 'lid (instrument to cover)' $\leftarrow p^{h}$ ว́m 'to cover'

It is beyond the scope of this paper to start further discussions on the fossilised forms in Khroskyabs, but one should keep in mind that the Rgyalrong type of relativisation, or at least nominalisation, once existed in Khroskyabs.

\footnotetext{
${ }^{6}$ Khroskyabs $v$ - corresponds regularly to Japhug and Cogtse Situ $p$ - and Bragdbar Situ $v$ - or $p$-, and Khroskyabs $-i$ corresponds to Japhug, Cogtse Situ $-a$ and Bragdbar Situ -ie or -ia: Khroskyabs rvî :: Japhug

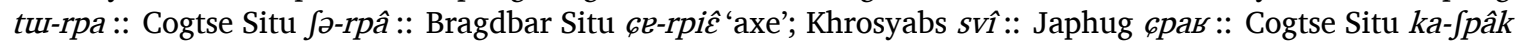
:: Bragdbar Situ kə-ఢpiâk 'to be thirsty'.
} 


\section{Correlative-like constructions}

Wobzi exhibits a type of correlative-like relativisation. Correlative is "a left-peripheral relative clause linked to a nominal correlate in the clause that follows the relative clause" (Lipták 2009: 1). In Wobzi, these constructions appear with interrogative pronouns sô

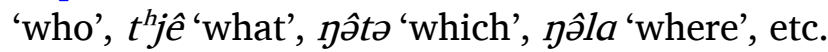

However, such constructions are not proto-typical correlatives in that 1) it does not necessarily require a correlate (usually a resumptive pronoun, for instance the case of Hindi, see Grosu and Landman 1998: 164-165) in the matrix clause, and that 2) they can be nominalised as well as bare sentences (de Vries 2002: 40).

(50) $S / A$ correlative

a. $S$

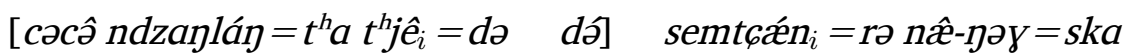

DEM world $=$ LOC what $=$ also exist ${ }_{1}$ be $=$ TOP IPFV.PST.Q-be ${ }_{2}=$ TOP

$s æ p^{h} \hat{o}-p^{h} u=r \partial \quad n \hat{x}-\not j \partial \gamma \quad n \partial j e ̂ t^{h} \hat{a} \quad v \hat{1}-n \quad n d z o^{\prime}$

tree-REDUP $=$ TOP IPFV.PST.Q-be 2 2SG goodness do $_{1}-2$ must $_{1}$

All that is in the world, no matter what it is, animals or plants, you should arrange them well.

b. $A$

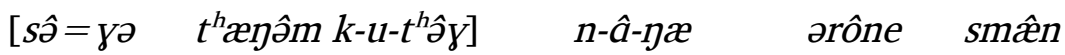

who $=$ ERG disease PST-INV-take ${ }_{2}$ NPST-IRR-be ${ }_{1}$ radically medicine

$v \hat{\imath}=s p i \quad n æ-m \hat{\imath}=p a \quad r \partial-\eta \hat{x}$

do $_{1}=$ NMLZ:A IPFV.PST-not.exist ${ }_{2}=$ NMLZ NPST-be $_{1}$

For those who contract an disease, there is no medicine at all.

(51) Possessor correlative

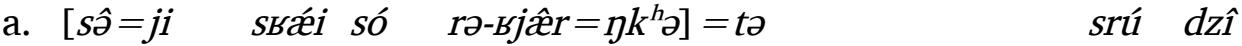
who $=$ GEN voice more NPST-be.beautiful ${ }_{1}=$ NMLZ:Poss $=$ DEF $_{\text {meat eat }}$

jáy

permit $_{1}$

The one whose voice is more beautiful can eat the meat.

b. $\left[\right.$ brô $\left.\eta \hat{\partial} t \partial \quad b j \hat{\partial} m=\eta k^{h} \partial\right]=t \partial=y \partial \quad t^{h} o ́ v \quad n d z e ́=s p i$

horse which be.quick $1=$ NMLZ:Poss $=$ DEF $=$ ERG authority obtain ${ }_{1}=$ NMLZ

u-ví rə-クæz

PST.INV-do ${ }_{2}$ NPST-être

The one whose horse is faster will be made king.

(52) P correlative

$\left[t^{h} \hat{e}_{i}\right.$ vî $\left.=s p i\right] \quad<$ bàn fă $>$ râyi $f_{s æ m n u ̂ y}=s p i$

what $\mathrm{do}_{1}=$ NMLZ:P.IRR solution one think $\mathrm{N}_{1}=$ NMLZ:P.IRR

$n æ-d \hat{\partial}=s i$

IPFV.PST-EXIST ${ }_{2}=$ IFR 
He found a way (literally: He found what he should do).

(53) Oblique correlative

a. $\left[s \hat{z}=k^{h} e \quad n t c u ́ g r i n-\hat{a}-k^{h} a\right]=t o \quad t s^{h} \hat{a} \sim t s^{h} a \quad$ vî $\quad$ ró qui $=$ DAT salary $\quad$ NPST-IRR-give ${ }_{1}=$ DEF well $\sim$ REDUP do $_{1}$ must $_{1}$ Those to whom we give salary must work hard.

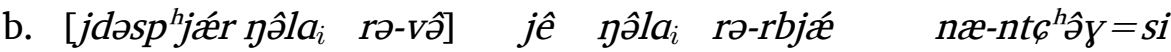
wave where NPST-go ${ }_{1} 3$ SG where NPST-arrive ${ }_{1}$ PST- $\mathrm{gO}_{2}=\mathrm{IFR}$ He went where the wave went.

\section{Genitive as relative marker}

\subsection{Overview of genitive relativisers in Trans-Himalayan}

In his original article, Bickel (1999) uses the term STANDARD SinO-TIBETAN NOMINALISATION (also mentioned in Section 4) to account for the morphological unification of genitivisation, relativisation and nominalisation in "many, if not most" Trans-Himalayan languages. If we exclude genitivisation, as DeLancey (2002: 56) states, "the identity of relativisation with nominalisation constructions does seem to be nearly universal throughout the family". Genitivisation as means of relativisation is less common, but can still be found in different branches of the family.

In Sinitic languages, such as Mandarin Chinese and Cantonese, the genitive marker is used as the relativiser (Chao 1947: 44-45), illustrated in (54).

a. Mandarin
教書 的 人
jiào-shū de rén
teach-book GEN person
the one that teaches

b. Cantonese

$$
\begin{aligned}
& \text { 教書 嘅 人 } \\
& \text { gaau }^{3}-\mathrm{syu}^{1} \mathrm{ge}^{3} \mathrm{jan}^{4} \\
& \text { teach-book GEN person } \\
& \text { the one that teaches }
\end{aligned}
$$

In Lahu, the same marker ve is used for nominalisation, genitivisation and relativisation (Lahaussois 2002, Matisoff 1972), see (55).

\section{a. Genitive}

நà ve mí-cho

1SG GEN shoulder-bag

my handbag

\section{b. Relative}


và? qhe chu ve Pîcho-pāô te Jâ

pig like fat GEN Shan DEM one person

the Shan there that is as fat as a pig

Classical Tibetan, however, employs the genitive marker after nominalisers (DeLancey 2002: 57), see (56).
a. [shi-ba-'i] ro die-NMLZ-GEN body a dead body
b. $\quad[$ slob $=$ dpon med-pa-'i $] \quad$ brtul=zhugs-chan 'di teacher not.exist-NMLZ-GEN ascetic DEM this ascetic who has no teacher

Unlike the above languages, Rgyalrongic languages are rarely reported to use genitivisation as the main strategy of relativisation. Japhug is found to present its genitive marker $y u$ in some of the cases of oblique relativisation, illustrated in (57). However, genitive is never attested for relativisation of core arguments.

a. Time

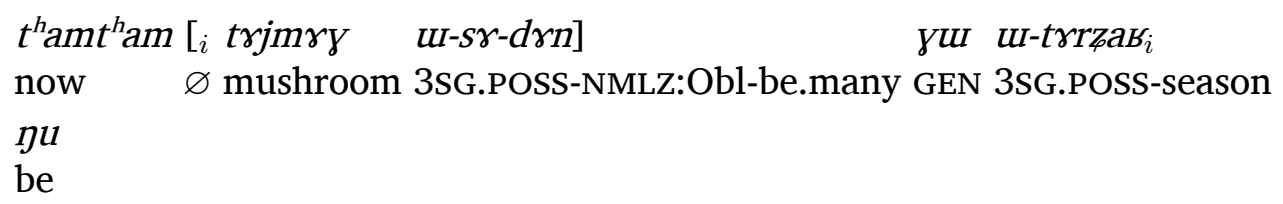

This is the season when there are more and more mushrooms. (Jacques 2008: 334)

b. Instrument

tce $k \gamma$-yrme ftcaka nu [tu-nga u-tas tce ${ }_{i}$ qaju

LNK INF-lose method DEF POSS.INDEF-clothes POSS.3-surface LNK $\varnothing$ bug

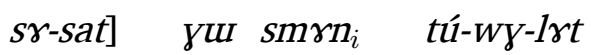

NMLZ:kill GEN medicine IPFV-INV-release

The way to get rid of the them is to put insecticide used to kill bugs on the clothes. (Jacques 2015: 108)

In Khroskyabs dialects, it is generally considered grammatical to add the genitive marker $=j V$ to nominalisers just like Classical Tibetan (this kind of constructions is very rarely employed, only pronounced when elicited), while adding the genitive marker without a nominaliser is in most cases unacceptable, even totally unacceptable for core arguments in some dialects such as Siyuewu. The Wobzi dialect, however, presents a larger freedom in using the genitive marker for relativisation, which will be described in the next section. 


\subsection{Genitive relativiser in Wobzi Khroskyabs}

Like Japhug, Wobzi Khroskyabs (probably with other Khroskyabs dialects, at least Siyuewu) allows the genitive marker to relativise time and place adjuncts, which are, obviously, two of the most oblique arguments. See the examples in (58), =ji is added to the relative clause without any nominaliser overtly preceding. In (58a), the form $=s k a$ must be analysed as a noun instead of a nominaliser.

a. Time

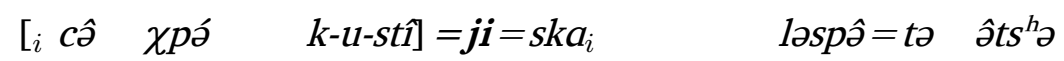

$\varnothing$ DEM mugwort NPST-INV-put $1=$ GEN $=$ time body $=$ DEF a.little

$$
\text { skí.cæ ntc }{ }^{h} \mathfrak{x}^{\prime}
$$

be.hot $_{1}$.TRANS 1 will 1

When we apply the mugwort, the body will feel a little hot.

b. Place

$$
\begin{aligned}
& \text { cô }\left[\text { cælná }=y \partial_{i} \text { lbé } n \text {-u-lî] }=\mathbf{j i} \quad \text { <piàn pian }>_{i}=\right.\text { tə ndôru } \\
& \mathrm{DEM} \text { child }=\mathrm{ERG} \varnothing \text { urine PST-INV-release }{ }_{2}=\mathrm{GEN} \text { diaper }=\mathrm{DEF} \quad \text { look.for }_{1} \\
& \text { We look for a diaper on which a child has urinated. }
\end{aligned}
$$

The Siyuewu dialect of Khroskyabs does not allow other arguments to be relativised by the genitive marker, however, in Wobzi, the instrument is also found to be relativised by genitive $=j i$, see example (59).

(59) Instrument

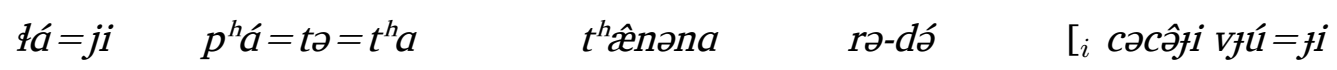

God $=\mathrm{GEN}$ mountain $=\mathrm{DEF}=\mathrm{LOC}$ no.matter. what NPST-EXIST $1 \varnothing 3 \mathrm{PL}$ man $=\mathrm{PL}$ scêre mə-dár mə-sô] $=j i \quad$ cântu $\eta_{i} d z \hat{\imath}=s p i \quad$ rə-dó

life NEG $_{1}$-be.old ${ }_{1} \mathrm{NEG}_{1}$-die ${ }_{1}=$ GEN fruit eat ${ }_{1}=$ NMLZ:P.IRR NPST-exist $_{1}$

In the Divine Mountain, there is all that we need. There is a fruit with which people do not get old or die.

The Wobzi genitive marker does not stop at the relativisation of peripheral adjuncts, it is also grammatical with the intransitive $S$, as shown by the examples in (60).

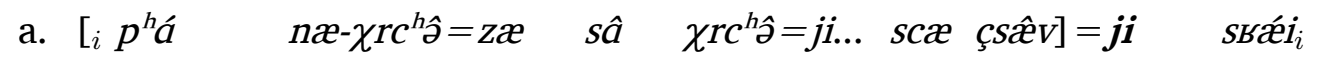
$\varnothing$ mountain NPST-split $_{1}=$ and earth split $_{1}=$ GEN only be.like ${ }_{1}=$ GEN sound rây næ-rtsh $\hat{\partial} m=s i$ one PST-Sound ${ }_{2}=$ IFR There was a sound that resembled mountains and the ground being split apart.

b. $\left[{ }_{i}\right.$ bré $]=j i \quad p^{h} a y t c^{h}{ }_{1}=t \partial_{i} \quad$ rgəmé $=q^{h} r a=g \partial=t^{h} a k-u-t u ́=s i$ $\varnothing$ be.high $_{1}=$ GEN sideway $=$ DEF stone $=$ big $=\mathrm{CL}=$ LOC PST-INV-twine ${ }_{2}=$ IFR It twined on a big stone on the higher sideway. 
Transitive arguments are rarely relativisable with the genitive marker in Wobzi, and completely impossible in Siyuewu. In Wobzi, elicitation of genitive relativisation usually fails. Nevertheless, we do find two non-elicited instances of P-relativisation with it in our database, illustrated in (61). The other core argument in a transitive construction, the A, however, is never found to be relativised with the genitive marker, nor is such constructions considered grammatical in any elicitation.

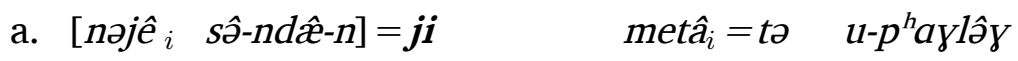

2SG $\varnothing$ SUPERL-love $_{1}-2 \mathrm{SG}=$ GEN flower $=$ DEF PST.INV-overturn ${ }_{2}$

It overturned the flower that you like the most.

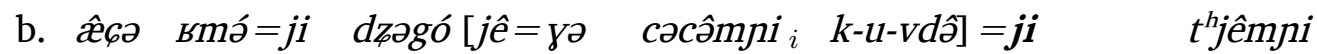
CONJ fire $=$ GEN front $3 \mathrm{SG}=\mathrm{ERG}$ like.this $\varnothing$ PST-INV-taste ${ }_{2}=\mathrm{GEN}$ how

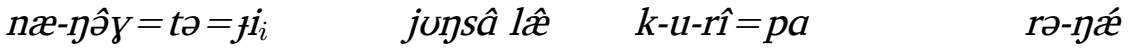

$$
\begin{aligned}
& \text { IPFV.PST-be }{ }_{2}=\mathrm{DEF}=\text { PL again always PST-INV-write }{ }_{2}=\text { NMLZ NPST-be }_{1}
\end{aligned}
$$

Then, he wrote down whatever he had tasted in front of the fire.

In summary, compared to other Khroskyabs dialects even other Rgyalrongic languages, the genitive marker in Wobzi Khroskyabs enjoys a wider possibility regarding relativisation: not only can it relativise place and time adjuncts, it can also relativise instruments and the $S$, and even the $P$ in a marginal sense. Table 13 shows the functions covered by genitive relativisation in both Wobzi and Siyuewu Khroskyabs.

Table 13: Genitive relativisation in Wobzi and Siyuewu Khroskyabs

\begin{tabular}{lcc}
\hline Argument & Wobzi & Siyuewu \\
\hline A & $\boldsymbol{x}$ & $\boldsymbol{x}$ \\
S & $\checkmark$ & $\boldsymbol{x}$ \\
P & marginal & $\boldsymbol{x}$ \\
R & $\boldsymbol{x}$ & $\boldsymbol{x}$ \\
Instrument & $\checkmark$ & $\boldsymbol{x}$ \\
Time & $\checkmark$ & $\checkmark$ \\
Place & $\checkmark$ & $\checkmark$ \\
Possessor & $\boldsymbol{x}$ & $\boldsymbol{x}$ \\
\hline
\end{tabular}

\section{From genitive to relative marker: the evolutionary pathway}

It has been shown above that genitive relativisation is rather not common even in Khroskyabs, not to mention Rgyalrongic, despite its being seemingly wide-spread in Trans-Himalayan. Wobzi is innovative from this point of view amongst Khroskyabs dialects, given its wider possibility to relativise core arguments. This section will focus on how genitive became (and is still becoming) one of the relativising devices in this dialect. 


\subsection{Hypothesis 1: calque of Chinese relatives}

Since the nominalisation strategy in Khroskyabs is a constructional calque of Tibetan, the religiously and culturally dominant language of the region, it may not seem absurd that genitivisation as relativisation is also a calque, but of a different origin: Chinese that is rapidly becoming the most important second language of Khroskyabs speakers. As mentioned in Section 7.1, Chinese relatives make use of the genitive marker.

Relativisation of core arguments of transitive constructions is the most unusual case of genitive relativisation in Wobzi Khroskyabs. Our two examples of P-relativisation using the genitive marker (Example 61), although not direct elicitations, are extracted from the retelling of stories originally written in other languages, Example (61a) from Tibetan, and Example (61b) from Chinese. The process of retelling may cause overliteralness in translation and unnatural grammatical constructions to occur, especially when the language consultants are not professional interpreters, which is the usual case.

However, even though one cannot fully deny the role that language contact plays, the shortcomings of the calque hypothesis are not negligible. First, overliteralness in translation should have little influence here, because the two sentences in question are not literally translated from their original sources; instead, the speaker retold the story with her own expressions. The two original sentences related to the two examples are Example (62a) for (61a), and (62b) for (61b). We can clearly see that the original sentences are both structurally and semantically distinct from the retold sentences.

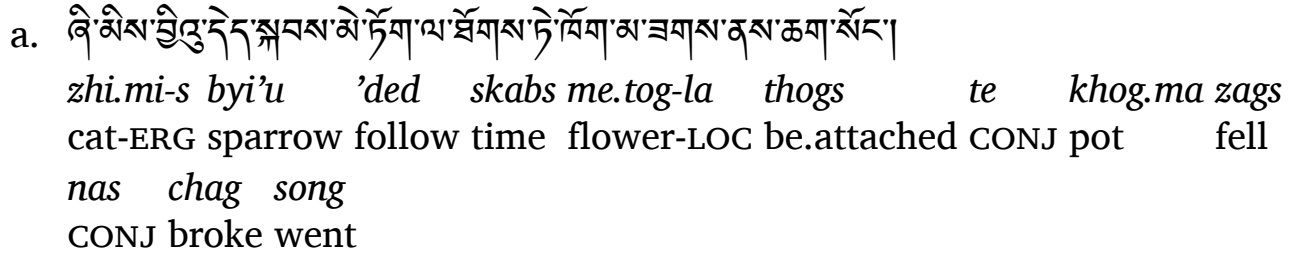

When the cat was chasing the sparrow, it hit the flower pot, overturned and broke it.

b. 他就着火光把尝百草的体验详细记载下来

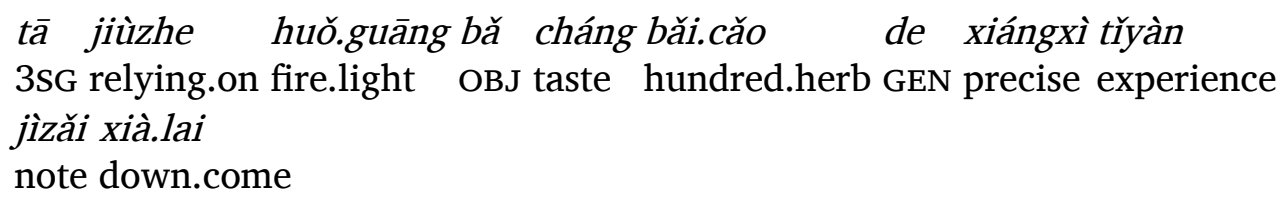

He wrote down his experience of tasting the herbs with precision by the fire.

Second, as is shown in Table 13, the distribution of the genitive marker presents definitive boundaries, with strict impossibility for the A, the $\mathrm{R}$ and the possessor, while productivity with the $S$, the instrument, the time and the place, and the only marginal case, concerns the P. If it were a calque, we would expect that the use of genitive for relativisation be evenly distributed for all arguments or adjuncts or a continuum of occurrences of genitive following a certain order (for instance, the Accessibility Hierarchy), but neither is observed. In the database, as far as transitive core arguments are concerned, 81 examples of A-relativisation and 59 of P-relativisation are attested; 
the fact that no instance of A-relativisation with the genitive marker is found would be surprising if the calque hypothesis were valid, given that A-relativisation significantly outnumbers P-relativisation.

Another deficiency of this hypothesis is that it is hardly testable. This "calque" is not as obvious as that of the relativisation through nominalisation, which is clearly from Tibetan, since it shows identical unusual uses (e.g. modal division of P-relativisation); it is also difficult to find out substantial evidence to support this theory, therefore nearly impossible to set up testing criteria.

\subsection{Hypothesis 2: spread from lower-ranking arguments}

Since time and place adjuncts are relativisable with genitive across Rgyalrongic languages, one can regard them as the starting point of the spread of genitive relativisation through the Accessibility Hierarchy, from which the use of genitive relativisation could have gradually spread closer to core arguments. This process is typologically plausible, as Romaine (1984: 445, 463) states, new strategies of relativisation will enter a language in reverse order on the Accessibility Hierarchy, in other words, from low to high, and the spreading process should be gradual. Examples can be found amongst Germanic languages, where wh-relatives started out with only low-ranking adjuncts, and spread to the higher ranking ones to different degrees (Romaine 1980: 233; Wagener 2017: 192).

However, if we observe Table 13 again, we will find the spreading hypothesis is only valid to a limited extent. First of all, the use of genitive $=j i$ does not start from the lowest slot that is relativisable, the possessor, rather, it skips the possessor and is directly applied to time and place adjuncts; second, the R, situated between oblique adjuncts and core arguments, is skipped off from the putative spread. Therefore, genitive relativisation cannot have spread up along the Accessibility Hierarchy.

\subsection{Hypothesis 3: the ergative pathway through analogy of noun comple- mentation}

It is shown that the previous two hypotheses are both unsatisfactory, we therefore need to search for more plausible explanations. In this section, I will come up with a third hypothesis exploring the ergative pivot of genitive relativisation in Wobzi, accompanied by the analogy of noun complementation, which triggers the evolution.

\subsubsection{Ergative pivots}

The genitive marker $=j i$, as a relativiser, is productive in S-relativisation and marginally available for P-relativisation, as far as core arguments are concerned. A-relativisation is however never touched by $=j i$. In short, except for the relativisation of oblique adjuncts, only the relativisation of a part of core arguments is concerned with the genitive marker. Relativisation of oblique adjuncts with the genitive marker is shared by Rgyalrong languages, which indicates its antiquity, while S/P relativisation with the genitive marker is only observed in Wobzi, which means it is a recent development. 
The examples of P-relativisation with the genitive marker are admittedly few in number, however, it does not mean that one should completely ignore them. First, the examples we show are not directly elicited (see Section 8.1); second, they are not of extremely complex syntactic structures, therefore the speakers have no need to force themselves to find a solution through calquing or borrowing; third, as I have mentioned above, it is curious that the genitive marker never appears in A-relativisation, but occurs in P-relativisation of which the total number is fewer. This fact would mean that genitive relativisation of the $\mathrm{P}$ does not appear by accident.

According to the data, we can see that the genitive marker $=j i$ has completed its invasion of S-relativisation, and infiltrates the relativisation of the P. That it does not affect the relativisation of the A may be an indication that this infiltration follows an ergative pattern, where the $P$ is treated in the same way as the $S$, instead of the A. Figure 1 visualises the pathway. Genitive relativisation in Wobzi therefore probably presents an ongoing evolution towards ergative pivots among core arguments.

Figure 1: The ergative pathway of $=j i$

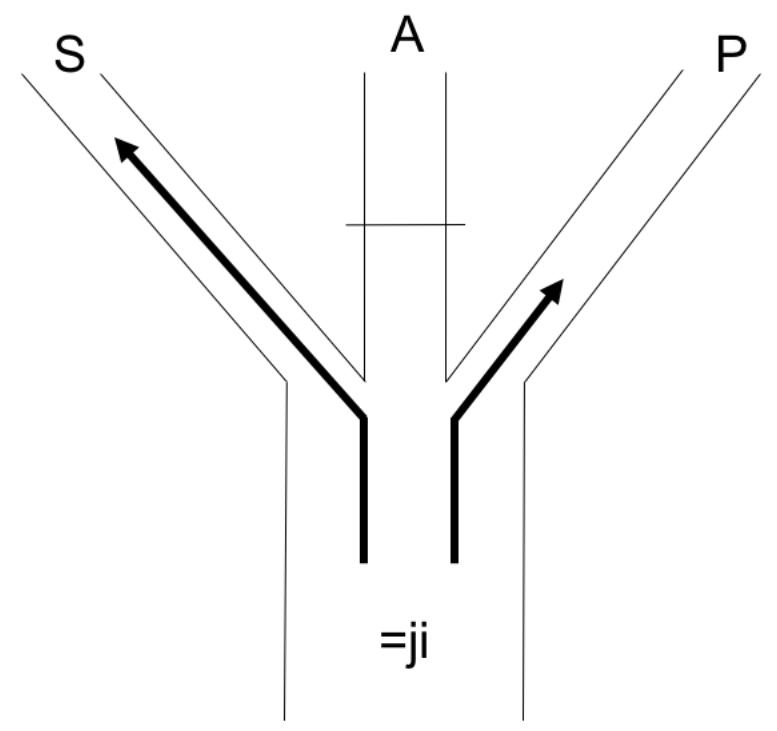

If this hypothesis is valid, we might expect that T-relativisation can also be marked by genitive $=j i$, because the $\mathrm{T}$ behaves in the same way as the $\mathrm{P}$ in our database. However, no such examples are found yet.

\subsubsection{Analogy of noun complementation}

In this section, I discuss how the genitive marker made it to relativise core arguments, especially the $S$, in addition to oblique adjuncts. My hypothesis is that it is due to the analogy of noun complementation.

Although some scholars, such as Kayne (2010) and Comrie (1998), analyse noun complementation as relativisation, in this paper, we keep the distinction between the two. 
As Jacques (2016a: 239) states, "for the purpose of detailed language description it is always err on the side of splitting than on that of lumping". The head noun of a relative clause has a syntactic role presented in Section 3.1, while that of a complement clause does not. This said, ambiguities can be found in Wobzi Khroskyabs.

In Wobzi Khroskyabs, as well as other Khroskyabs dialects, complements of nouns are systematically preceded by the genitive marker $=j i$, see the examples in (63).

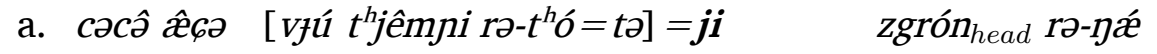

DEM CONJ man how $\quad$ PST-come $_{2}=$ DEF $=$ GEN story $\quad$ NPST-be $_{1}$

This is the story how humans came into being.

b. ætâmni n-â-вbay $\quad$ cə jê $=j i \quad j u n s a ́ ~[s c \hat{t} t]=j i$

like.that PFV-IRR-be.many ${ }_{1}$ CONJ PRON.REFL $=$ GEN again be.happy ${ }_{1}=\mathrm{GEN}$

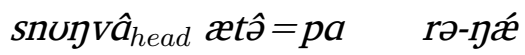

feeling $\quad \mathrm{DEM}=$ NMLZ NPST-be ${ }_{1}$

If (the mountain deity) gets a satisfactory amount (of tributes), he will be happy (he will have a feeling of happiness).

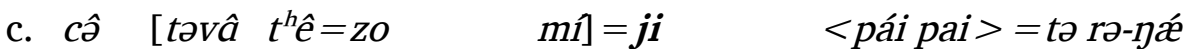

DEM smoke absorb ${ }_{1}=$ NMLZ not.exist $_{1}=$ GEN board $=$ DEF $\quad$ NPST-be $_{1}$

This is the no smoking sign.

The embedded clauses presented in (63) cannot be analysed as relatives, since their head nouns are relativisable arguments; they can only be regarded as complement clauses modifying the head nouns. However, these constructions are structurally and even semantically similar to relative constructions, especially S-relativisation. We can easily translate those sentences with relative clauses in English: the examples (63a) and (63b) can be semantically (although not syntactically) reinterpreted as S-relatives, this is the story that is about how humans came into being, and he will have a feeling that is happy respectively, and Examples (63c) can be either an S-relative, this is the sign that reads "no smoking", or an instrument relative, this is the sign used to ban smoking. Such ambiguities may trigger the reanalysis of the marker $=j i$, from an original genitive marker to a relativiser.

In a same narrative, we do find a pair of constructions bearing close meanings, one of which has a head noun that takes a complement clause, and the other a head noun taking a relative clause just by adding a simple verb, illustrated in (64).

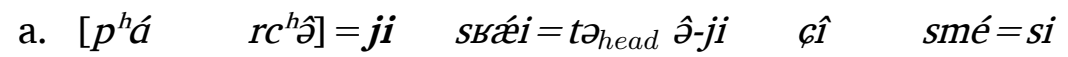
mountain split $_{1}=$ GEN sound $=\mathrm{DEF}$ one-CL always hear ${ }_{2}=\mathrm{IFR}$ He heard the sound of splitting mountains.

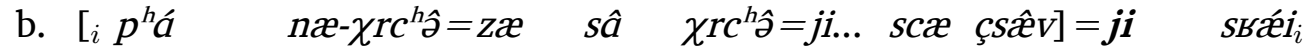
$\varnothing$ mountain NPST-split $1=$ and earth split $_{1}=$ GEN only be.like ${ }_{1}=$ GEN sound rây $n æ-r t s h \hat{\partial} m=s i$ one PST-Sound ${ }_{2}=$ IFR

There was a sound that resembled mountains and the ground being split apart.

The embedded clauses in (64) both describe the resemblance of a sound to that produced by mountains and the ground splitting apart. However, Example (64b) presents 
a relative clause, in which the head noun, sьǽi rây 'a sound' is the $S$ of the verb çsæ̂ $V$ 'resemble'; Example (64a) presents a complement clause, since the head noun, sьǽi $i$ to 'the sound', cannot be an argument of the clause. Despite the subtle structural difference, we can see the overall appearance and the semantics of these two examples are very close to each other. This pair of subordinate clauses can be therefore considered as a living example of the marker $=j i$ swaying between noun complementation and S-relativisation.

My stance in this paper is to concur with the hypothesis presented in this section that the marker $=j i$ enters S-relativisation through the analogy of noun complementation, due to subtle semantic and structural ambiguity, creating a continuum between noun complementation and relativisation, and then spread to P-relativisation following an ergative pathway, illustrated in Figure 2.

Figure 2: Evolutionary pathways of the marker $=j i$

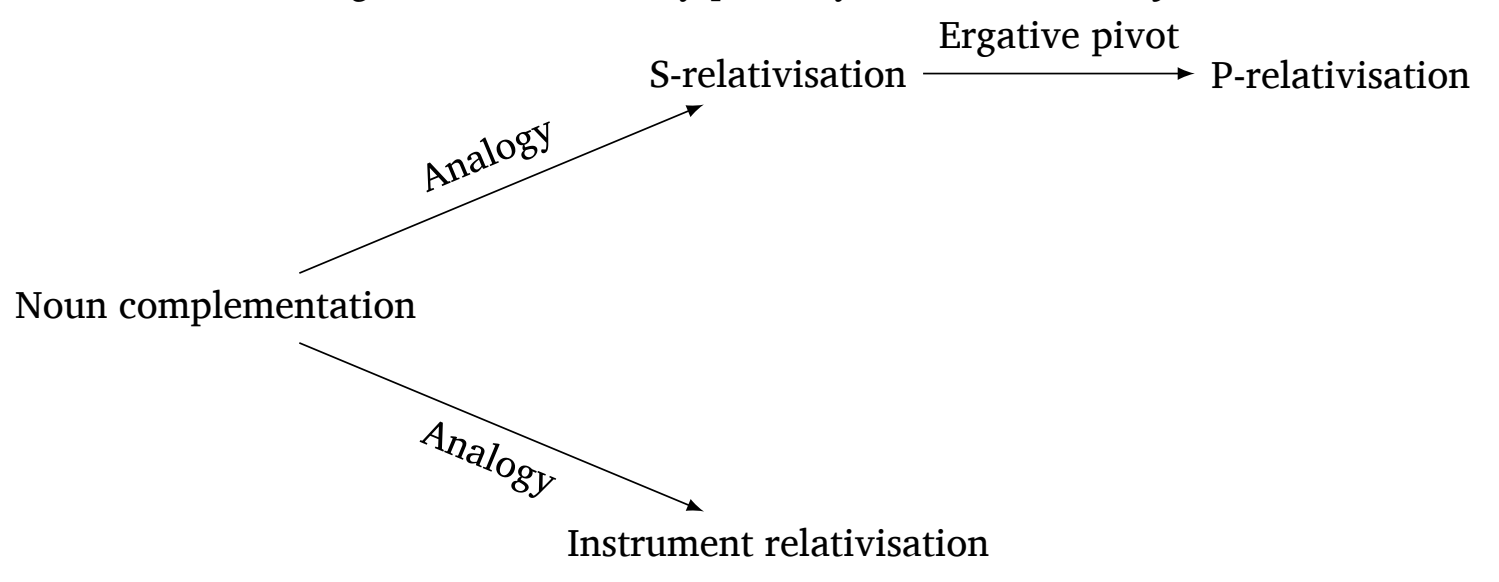

\subsubsection{Comparative remarks}

In the previous section, I came up with a pathway towards relativisation, starting from genitivisation. While it is probably the case in Khroskyabs, this pathway does not seem to be universal across Trans-Himalayan languages. DeLancey $(1986,2002)$ shows a reverse pathway in Kathmandu Newari, in which the relativiser gu(li), itself from the homophonous nominaliser, actually developed into a genitiviser. Delancey also states that the Lahu relativiser/genitiviser ve followed the same pathway.

The Mandarin Chinese relativiser/genitiviser 的 $d e$ underwent the same reverse process as Newari and Lahu, as observed by Shi and Li (2002: 13-14). The genitive use of de in Mandarin is apparently the very latest amongst its other uses, having emerged in the 12th century, whereas the relative use emerged in the 9th century.

As for Old Chinese, Shi and Li (2002: 6) state that the genitiviser 之 *to (Mandarin zhi ) had three main functions, it was employed for genitive phrases, relative phrases and associate phrases, with the last use presumably including noun complementation. No comments have been made to judge which use was original. They cited examples from the Analects of Confucious (around 500-200 BC) for genitive and relative uses, and 
an example from Shì Shuō Xīn Yǔ (425 AD) for the associate phrase use, which dates more than half a millennium after the Analects. However, one may easily find noun complementation with 之 *to in Old Chinese of the same period as the Analects:

a. 如知為君之難也

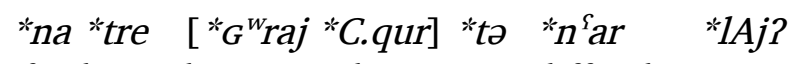

if know be ruler GEN difficulty PART

If one knows the difficulty to be a ruler... (The Analects, Zìlù 15)

b. 固相師之道也

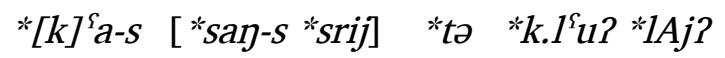

radically assist master GEN way PART

This is certainly the way to assist a master. (The Analects, Wèi Líng Gōng 42)

c. 為我作君臣相說之樂

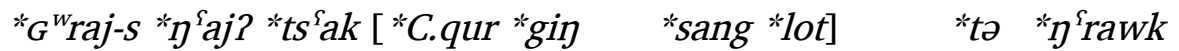

for 1SG make ruler minister RECP be.pleased GEN music

Compose a piece of music about the ruler and ministers being happy and harmonious together. (Mèngž̌, Liáng Hùi Wáng 2:11)

Therefore, in Old Chinese, the three uses of the marker "to coexisted, with the possibility that it spread quickly from one use to all. It is however hard to determine whether the directionality was identical to that of Wobzi Khroskyabs.

\section{Conclusion}

Relativisation in Khroskyabs is of interest from the perspectives of typology and historical linguistics. Nominalisation is the main strategy. Nominalising enclitics are used to relativise different funtions through the possessor to the core arguments included in the Accessibility Hierarchy. Externally-headed relative clauses can either precede or follow the head noun, which, according to Andrews (2007: 211), is typologically rare. Internallyheaded relatives are also attested in Wobzi Khroskyabs, whose heads are prohibited from definite marking.

It is safe to say that the nominalising strategy is a result of language contact with Tibetan, since a good part of the markers are borrowed from Tibetan, and the unusual modal division of P-relativisation is attested in both languages. Khroskyabs adopted the Tibetan type of nominalisation/relativisation to replace its original Rgyalrong type.

A new type of relativisation using the genitive marker $=j i$ is observed in Wobzi Khroskyabs, with a wider range of relativisable arguments than other Khroskyabs dialects as well as Rgyalrong languages. Genitive $=j i$ can not only relativise oblique adjuncts (time, place, instrument), but also the $S$ and even the $P$. Its evolution drew our attention and several hypotheses were proposed. The most plausible hypothesis states that $=j i$ extended its relativising capability by analogy of noun complementation, and followed an ergative pathway during its spread within core arguments. The pathway from genitivisation 
towards relativisation is by no means common cross-linguistically, as Hendery (2012: 88) notes, there are few languages found with this pathway, and it would be more secure to say that "the relative marker was extended to possessive (genitive)". Our study however shows that the possibility for the genitive marker to become a relative marker.

Different types of syntactic pivots are attested, as shown in Table 14. The ergative pattern seems to be productive since it is adopted by the new comer, genitive relativisation.

Table 14: Syntactic pivots in relativisation in Wobzi Khroskyabs

\begin{tabular}{l|l|l}
\hline \multicolumn{2}{c|}{ Type } & Syntactic pivots \\
\hline \multirow{2}{*}{ Externally-headed nominalised } & Realis & Neuter \\
\cline { 2 - 3 } & Irrealis & Accusative \\
\hline Internally-headed nominalised & Ergative \\
\hline Genitive & Ergative \\
\hline
\end{tabular}

Relativisation in Khroskyabs shows radical differences from Rgyalrong languages, though traces of the Rgyalrong type of relativisation can be found without productivity. Wobzi Khroskyabs presents a more innovative system than Siyuewu Khroskyabs, as we have seen in this paper, the system is still visibly evolving. Data of other Khroskyabs dialects are still insufficient today, future findings on Khroskyabs relativisation may give us a clearer picture of the evolutionary pathways.

\section{Abbreviations}

Abbreviations: A: agentive argument, P: patientive argument, S: intransitive subject, T: theme, R: recipient, ABL: ablative, ALL: allative, ASSRT: assertive, CL: classifier, CONJ: conjunction, DAT: dative, DEF: definite, DEM: demonstrative, ERG: ergative, GEN: genitive, GENERIC: generic, IFR: inferential, IMP: imperative, INF: infinitive, INSTR: instrumental, INV: inverse, IPFV: imperfective, IRR: irrealis, JUSS: jussive, LOC: locative, NEG: negative, NMLZ: nominaliser, NPST: non-past, PASS: passive, PFV: perfective, PL: plural, PROG: progressive, PRON.REFL: reflexive pronoun, PST: past, Q: interrogative, REDUP: reduplication, SG: singular, SUPERL: superlative, TOP: topicaliser.

Chinese loans or terms are presented in Pinyin between pointy brackets.

\section{Acknowledgements}

This research was supported by the ERC Starting Grant 715618 CALC. I would like to thank Guillaume Jacques, Gong Xun and the anonymous reviewer for their constructive suggestions. All faults are mine. 


\section{References}

Andrews, Avery D 2007. Relative clauses. In Shopen, Timothy (ed.), Language Typology and Syntactic Description (2nd edition), Vol. 2, 206-236. Cambridge: Cambridge University Press.

Auwera, J. van der and V. A. Plungian 1998. Modality's semantic map. Linguistic Typology 2(1): 79-124.

Basilico, David 1996. Head position and internally headed relative clauses. Language 72(3): 498-532.

Baxter, William H. and Laurent Sagart 2014. Old Chinese: a new reconstruction. Oxford: Oxford University Press.

Bickel, Balthasar 1999. Nominalization and focus constructions in some Kiranti languages. In Yadava, Yogendra P. and Warren G. Glover (eds.), Topics in Nepalese Linguistics, 271296. Kathmandu: Royal Nepal Academy.

Bickel, Balthasar 2004. Hidden syntax in Belhare. In Saxena, A. (ed.), Himalayan languages: past and present, 141-190. Berlin: Mouton de Gruyter.

Chao, Yuen Ren 1947. A Cantonese Primer. Cambridge, Mass.: Harvard University Press.

Comrie, Bernard 1998. Rethinking the typology of relative clauses. Language Design: journal of theoretical and experimental linguistics 1: 59-86.

Comrie, Bernard and Tania Kuteva 2005. Relativization Strategies. In Haspelmath, Martin, Matthew S. Dryer, Hans-Jörg Bibiko, Hagen Jung, and Claudia Schmidt (eds.), The World Atlas of Language Structures, . Oxford: Oxford University Press.

Coupe, Alexander R. 2007. A grammar of Mongsen Ao. Berlin and New York: Mouton de Gruyter.

Coupe, Alexander R 2017. Mongsen Ao. In Thurgood, Graham and Randy LaPolla (eds.), The Sino-Tibetan Languages (2nd edition), 277-301. Abingdon and New York: Routledge.

DeLancey, Scott 1981. An interpretation of split ergativity. Language 57(3): 626-57.

DeLancey, Scott 1986. Nominalization as relativization in Tibetan and Newari. Paper presented at the 19th International Conference on Sino-Tibetan Languages and Linguistics.

DeLancey, Scott 1999. Relativization in Tibetan. In Yadava, Yogendra P. and Warren G. Glover (eds.), Studies in Nepalese Linguistics, 231-249. Kathmandu: Royal Nepal Academy.

DeLancey, Scott 2002. Relativization and nominalization in Bodic. In Chew, Patrick (ed.), Proceedings of the 28th Annual Meeting of the Berkeley Linguistics Society, Parasection on Tibeto-Burman and Southeast Asian Linguistics, 55-72. Berkeley Linguistics Society. 
Genetti, Carol, Alexander R Coupe, Ellen Bartee, Kristine Hildebrandt, and You-Jing Lin 2008. Syntactic aspects of nominalization in five Tibeto-Burman languages of the Himalayan area. Linguistics of the Tibeto-Burman Area 31(2): 97-143.

Givón, Talmy 1990. Syntax: A Functional-Typological Introduction Vol. 2. Amsterdam: Benjamins.

Grosu, Alexander and Fred Landman 1998. Strange relatives of the third kind. Natural Language Semantics 6(2): 125-170.

Haller, Felix 2004. Dialekt und Erzählungen von Themchen, Sprachwissenschaftliche Beschreibung eines Nomadendialektes aus Nord-Amdo. Bonn: VGH Wissenschaftsverlag GmbH.

Hendery, Rachel 2012. Relative Clauses in Time and Space: A case study in the methods of diachronic typology. Amsterdam: John Benjamins.

Huang, Bufan 2007. Lawurongyu yanjiu 拉塢戎語研究 (Study on the Lavrung language). Beijing: Minzu chubanshe.

Jacques, Guillaume 2008. Jiarongyu yanjiu 嘉絨語研究 (Study on the Rgyalrong language). Beijing: Minzu chubanshe.

Jacques, Guillaume 2015. Dictionnaire Japhug-Chinois-Français version 1.0 嘉线 - 汉 - 法词 典 1.0版. Paris: Projet HimalCo http://himalco.huma-num.fr/.

Jacques, Guillaume 2016a. Complementation in Japhug Gyalrong. Linguistics of the TibetoBurman Area 39(2): 222-281.

Jacques, Guillaume 2016b. Subjects and objects in Japhug and relativization. Journal of Chinese Linguistics 44(1): 1-28.

Jacques, Guillaume, Anton Antonov, and Yunfan Lai unpublished. Khang.gsar Sta'u Dictionnary.

Jacques, Guillaume, Yunfan Lai, Anton Antonov, and Lobsang Nima 2017. Stau (Ergong, Horpa). In Thurgood, Graham and Randy LaPolla (eds.), The Sino-Tibetan Languages (2nd edition), 597-613. Abingdon and New York: Routledge.

Kayne, Richard S. 2010. Why isn't this a complementizer? In Kayne, Richard S. (ed.), Comparisons and Contrasts, 190-227. Oxford: Oxford University Press.

Keenan, Edward L and Bernard Comrie 1977. Noun Phrase Accessibility and Universal Grammar. Linguistic Inquiry 8(1): 63-99.

Lahaussois, Aimée 2002. Nominalization, relativization, and genitivization in Thulung Rai. In Chew, Patrick (ed.), Proceedings of the 28th Annual Meeting of the Berkeley Linguistics Society, Parasection on Tibeto-Burman and Southeast Asian Linguistics, 87-98. Berkeley Linguistics Society. 
Lai, Yunfan 2015. The Person Agreement System of Wobzi Lavrung (rGyalrongic, Tibetoburman). Transactions of the Philological Society 113(3): 271-285.

Lai, Yunfan 2016. Causativisation in Wobzi and other Khroskyabs dialects. Cahiers de Linguistique - Asie Orientale 45(2): 148-175.

Lai, Yunfan 2017. Grammaire du khroskyabs de Wobzi. PhD thesis, Université Paris 3 Sorbonne Nouvelle.

LaPolla, Randy 2008. Relative Clause Structures in the Rawang Language. Language and Linguisitics 9(4): 797-812.

Lipták, Anikó 2009. The landscape of correlatives. In Lipták, Anikó (ed.), Correlatives Cross-Linguistically, 1-48. Amsterdam: John Benjamins.

Malchukov, Andrej, Martin Haspelmath, and Bernard Comrie 2010. Ditransitive constructions: a typological overview. In Malchukov, Andrej, Martin Haspelmath, and Bernard Comrie (eds.), Studies in Ditransitive Constructions: A Comparative Handbook, 1-64. Berlin: De Gruyter Mouton.

Matisoff, James A 1972. Lahu nominalization, relativization, and genitivization. In Kimball, J (ed.), Syntax and Semantics I, 237-257. New York: Seminar Press.

Mazaudon, Martine 1978. La formation des propositions relatives en tibétain. Bulletin de la Société de Linguistique de Paris 73(1): 401-414.

Owen-Smith, Thomas and Nathan W Hill (eds.) 2014. Trans-Himalayan Linguistics. Berlin: De Gruyter.

Romaine, Suzanne 1980. The relative clause marker in Scots English: Diffusion, complexity and style as dimension of syntactic change. Language in Society 9(2): 221-247.

Romaine, Suzanne 1984. Towards a typology of relative-clause formation strategies in Germanic. In Fisiak, Jacek (ed.), Historical Syntax, 437-470. Berlin: De Gruyter Mouton.

Shi, Yuzhi and Charles N. Li 2002. The establishment of the classifier system and the grammaticalization of the morphosyntactic particle de in Chinese. Language Sciences 24(1): 1-15.

Shibatani, Masayoshi 2009. Elements of complex structures, where recursion isn't it. In Givón, Talmy and Masayoshi Shibatani (eds.), Syntactic Complexity. Diachrony, Acquisition, Neuro-cognition, Evolution, 163-198. Amsterdam: Benjamins.

Silverstein, Michael 1976. Hierarchy of Features and Ergativity. In Dixon, Robert M.W. (ed.), Grammatical Categories in Australian Languages, 112-171. Canberra: Australian Institute of Aboriginal Studies.

Sun, Jackson T.-S. 2006. Caodeng Jiarongyu de guanxiju 草登嘉戎語的關係句 (relative clauses in tshobdun rgyalrong). Language \& Linguistics 7(4): 905-933. 
Sun, Jackson T.-S. and Youjing Lin 2007. Constructional Variation in rGyalrong Relativization: How To Make a Choice? Paper presented at the International Workshop on Relative Clauses.

Van Valin, Robert and Randy LaPolla 1997. Syntax: Structure, meaning and function. Cambridge: Cambridge University Press.

Vries, Mark de 2002. The Syntax of Relativization. PhD thesis, Universiteit van Amsterdam.

Wagener, Terje 2017. The History of Nordic Relative Clauses. Trends in Linguistics, Studies and Monographs 304. Berlin: De Gruyter Mouton.

Williamson, Janis 1987. An indefiniteness restriction for relative clauses in Lakhota. In Reuland, E.J. and A.G.B. ter Meulen (eds.), The Representation of (In)definiteness, 168190. Cambridge, MA: The MIT Press.

Yin, Weibin 2007. Yelong Lawurongyu Yanjiu 业隆拉坞戎语研究 (Study on the 'Jorogs Lavrung language). Beijing: Minzu chubanshe.

\section{Author's contact address}

Lai Yunfan

Max Planck Institute for the Science of Human History

lai@shh.mpg.de 